\title{
A Report to the Connecticut Office of Policy and Management Regarding a Proposed Payroll Tax
}

Richard Pomp

University of Connecticut School of Law

Follow this and additional works at: https://opencommons.uconn.edu/law_papers

Part of the Taxation-State and Local Commons, and the Tax Law Commons

\section{Recommended Citation}

Pomp, Richard, "A Report to the Connecticut Office of Policy and Management Regarding a Proposed Payroll Tax" (2020). Faculty Articles and Papers. 569.

https://opencommons.uconn.edu/law_papers/569 


\title{
A Report to the Connecticut Office of Policy and Management Regarding a Proposed Payroll Tax
}

\author{
Professor Richard D. Pomp
}




\section{Table of Contents}

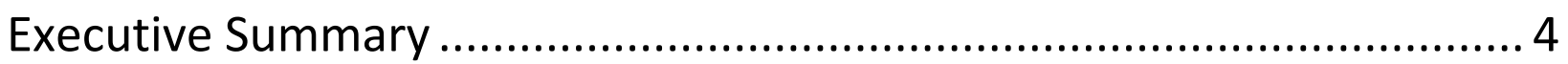

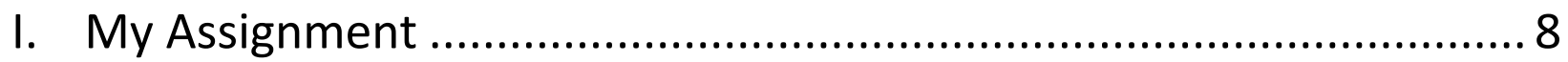

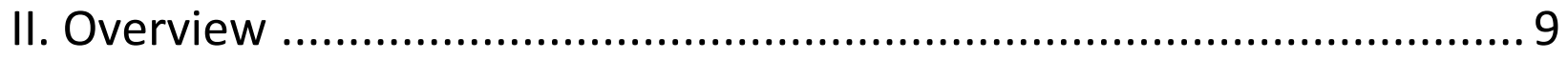

III. The Concept of a Payroll Tax .......................................................... 11

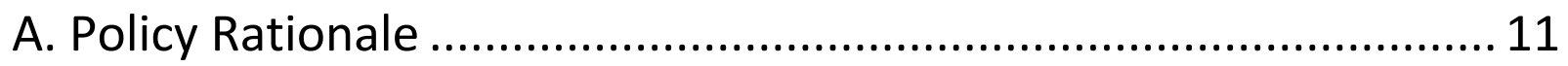

B. Who Should Benefit from Reducing Rates?.................................. 13

C. No Rate Reduction should be Extended to Non-Wage Income...... 15

D. Should the Base of the Payroll Tax be Tied to the Existing Withholding Tax on Wages? .............................................................. 16

E. Expected Reduction in Wages ..................................................... 19

F. The Payroll Tax as a Response to the Federal Cap on Itemized

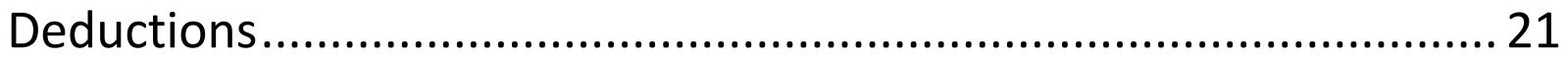

G. Employers' Response to a Payroll Tax.......................................... 24

H. Illustrative Examples .................................................................. 26

1. Effect on an Employee …........................................................... 26

2. Effect on Employer..................................................................... 32

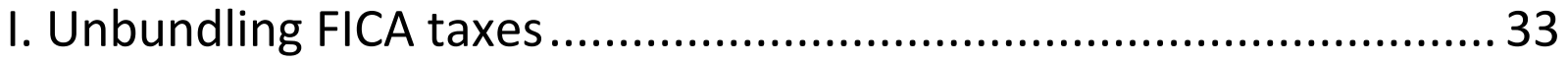

J. Effect on State and Federal Corporate Income Taxes from Reduced

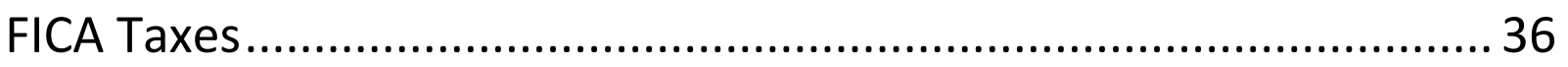

K. Effect on Connecticut and Federal Revenue from the Payroll Tax. 37

L. Minimum-Wage Earners .............................................................. 38 


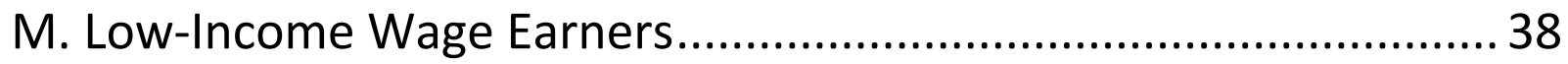

N. A New Rate Schedule: Version One ............................................. 41

O. A New Rate Schedule: Version Two ............................................ 43

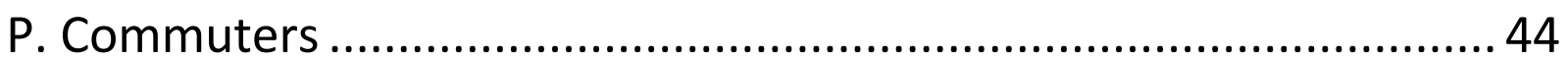

1. Connecticut Residents Commuting to other States ..................... 44

2. Resident of another State Commuting to Connecticut ................. 45

IV. Grand Summary: From the Weeds to the Forest ............................. 46

V. Will an Employer be able to Reduce Wages to Offset the Cost of the new Payroll Tax? ............................................................................ 48

1. Existing contracts controlling wages and wage increases.............50

2. The Special Case of the State as an Employer............................... 51

3. Employee Perceptions …............................................................. 54

4. Employer Perceptions …………………………....................... 57

VI. It is Uncertain Whether the Payroll Tax will Trigger the Retaliatory Tax Paid by Connecticut Insurers to other States in which they are

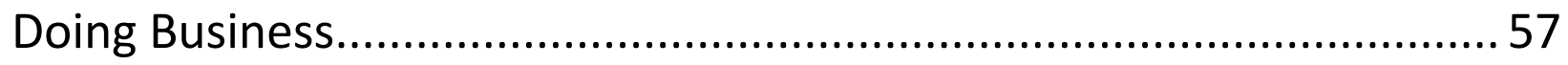

VII. A Payroll Tax Cannot be Imposed on the Federal Government

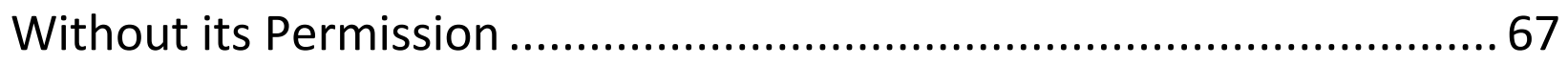
VIII. A Payroll Tax Cannot be Imposed on an Indian Tribe in its Capacity as an Employer Without its Permission................................................ 70 IX. Should the Payroll Tax be Mandatory or Elective? ............................ 72

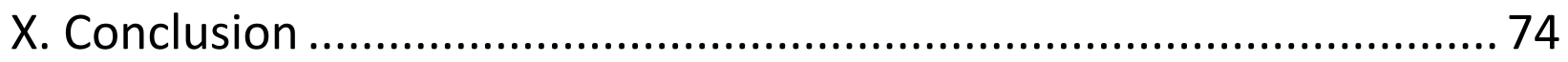




\section{Professor Richard D. Pomp ${ }^{1}$}

\section{Executive Summary}

This Report analyzes a 5\% payroll tax that would be imposed on employers on the amount of the wages they paid to their employees. The anticipated response is that employers would shift this tax to their employees. This shift would occur by the employers reducing their employee wages by the cost of the tax. Each of the existing rates in the personal income tax would be reduced by 5 points, which would have the effect of eliminating the $3 \%$ and $5 \%$ brackets.. This reduction in rates would be limited to wages and not apply to other items of income, such as dividends, interest, capital gains, rents, royalties and the like.

This reduction in rates should apply only if wages were reduced. Otherwise, employees would receive a windfall in having a tax reduction for no reason, and State revenue would be needlessly lost. Moreover, if employees were to receive the benefit of the tax reduction, little incentive would exist for them to support a reduction in their wages. A "tie-in" should be required; that is, the rate reduction should apply only if wages were reduced.

The dilemma with a tie-in is that it might be difficult to determine whether wages have been reduced or not, and to what extent. Many ways exist for an employer to reduce wages and some of these may not be transparent. And while the payroll tax assumes its cost will be

\footnotetext{
${ }^{1}$ A curriculum vitae and short summary of my background are found at the end of the Report. Sebastian lagrossi, a third-year student at UConn Law School, and the 2019 winner of the Stanley R. Arnold Scholarship, awarded by the New England State and Local Tax Forum, provided invaluable research for this Report.
} 
shifted to employees, it might be shifted backward to suppliers and independent contractors, or forward to customers.

A tie-in imposes another administrative complexity because there would be one rate schedule for those whose wages were reduced and another for those whose wages were not. But the advantages of a tie-in are considerable and merit a detailed exploration.

If the view is that employers are typically able to reduce their costs, and thus will be able to shift the payroll tax to employees, an explicit tie-in would be unnecessary. If the payroll tax is shifted to employees by reducing their wages, three consequences follow. First, an employee's federal income taxes would be reduced because of the lowered wages. Second, reduced wages mean an employee would pay lower FICA taxes (Social Security and Medicare). Third, the employer would also pay less FICA taxes.

Assuming wages would be reduced, then for most taxpayers the Connecticut and federal tax savings would more than offset the reduction in wages. Somewhat counter intuitively, these employees would have more take-home pay despite their wages being reduced. Less turns out to be more, at least in the short-term. But lower wages and hence lower FICA taxes will likely mean lower retirement income or lower Social Security benefits for many workers unless employers take actions to offset that reduction. Employers could use their FICA savings to subsidize this offset. In addition, disciplined employees could also invest their new tax savings for retirement.

For low-income taxpayers, the reduction in their wages would be more than their tax savings. One way of addressing this problem is through a refundable tax credit. Refundable tax credits, however, raise the possibility of fraudulent returns. 
Under the law, employers would not be able to reduce the wages of minimum wage employees. Consequently, one way of dealing with this issue is to exempt the wages paid to these employees from the payroll tax.

Suppose contrary to the assumption above, wages could not be reduced. Then the payroll tax would become an explicit tax on employers and not an implicit tax on employees. These employers would be saddled with a new $5 \%$ cost of doing business. They would receive no reduction in their FICA taxes. Unless there were a tie-in, their employees would nonetheless receive the benefit of the rate reduction. Under this scenario of no wage reduction, the tax would be shifted from employees to employers.

If the Legislature desires this shift in taxation, easier ways of achieving it exist, rather than in the guise of an ineffective payroll tax.

A critical threshold question, therefore, is whether employers will be able to shift the payroll tax to employees by reducing their wages. If they cannot, there is no reason to adopt a payroll tax. Answering this critical question would be avoided if the payroll tax were elective, rather than mandatory. Then only employers confident that they could reduce wages would opt into the payroll tax; the others would simply not make the election. A tie-in would prevent employees of employers that did not opt in from receiving a windfall.

New York has made its new payroll tax elective, and phases in its rates over three years. To date, only $0.1 \%$ of its employers have elected the tax. But New York's payroll tax is dissimilar to the Connecticut proposal. And the participation rate may be a function of how the payroll tax was explained and promoted. The New York experience needs further analysis. 
Nonprofits like hospitals, schools, the State, local governments and the like pay FICA taxes. If they can reduce their employee wages they will benefit from the lowered FICA taxes.

The State is in a different position from all other employers, whether they are non-profits or not. The State would be both the taxpayer and the recipient of the tax. It would not have to shift the tax to its employees because the tax is not a cost-the tax is a wash. Yet if its employees received the benefits of the rate reduction without any reduction in their wages, they could be perceived as getting a raise. The issue is whether the State should somehow recapture some or all of those benefits. This problem would be avoided if there were a tie-in.

A payroll tax cannot be imposed on the federal government without its permission, which is unlikely to be forthcoming. Similarly, a payroll tax cannot be imposed on an Indian tribe in its capacity as an employer on a reservation. Without a tie-in, the federal and tribal employees would be able to benefit from the state income tax rate reduction even though their wages had not been reduced. A tie-in would prevent this. Insurance companies are subject to retaliatory taxes, which are unique to that industry. It is uncertain whether the payroll tax will trigger retaliation. If retaliation results, Connecticut insurance companies will face increased costs in doing business in other states and be at a competitive disadvantage.

Implementing a payroll tax represents a major change to Connecticut's tax code, and the lack of a fully drafted bill hobbled what could be said in this Report with any certainty. There are many moving parts, many of which are interdependent. This Report identifies many of the questions needing answers. The Commission has a formidable challenge before it. 


\section{My Assignment}

I have been asked by the Office of Policy and Management to prepare a report covering the following areas:

a. Provide a high-level summary of who would benefit from a state payroll tax versus a state income tax for both itemizers and nonitemizers at the federal level.

b. Outline the major tenets of any other similar tax programs across the country.

2. Internal Revenue Service ${ }^{2}$

a. In crafting a payroll tax, what pitfalls do you foresee under which the Internal Revenue Service would prohibit a state payroll tax?

b. If a payroll tax were instituted and later prohibited by the Internal Revenue Service, who would bear the enforcement consequences under such a scenario and what remedies would taxpayers or the state have?

3. Federal Government/Tribal Nations

\footnotetext{
${ }^{2}$ The payroll tax may be the subject of future litigation between the federal government and Connecticut. My analysis of these issues in this Report would not be covered by any attorney-client privilege. Should there be litigation, discovery requests would likely extend to my work papers, drafts, and communications in preparing this Report. It is prudent that the State speaks with one voice in any potential litigation involving the characterization of the payroll tax. Consequently, my legal analysis of that issue should be deferred and take place in a manner where the attorney-client privilege applies. My caution should not be interpreted as my having reached a position or having even considered the merits of the questions posed-I have not.
} 
a. Provide an opinion on the ability of the state to impose a payroll tax on the federal government and tribal nations.

b. What legal arguments could the federal government or tribal nations make to avoid being subject to the tax?

4. Credit to Other Jurisdictions

a. Outline the tax consequences under the proposed payroll tax for individuals who work in other states yet reside in Connecticut.

b. Outline the tax consequences under the proposed payroll tax for individuals who work in Connecticut yet reside in other states.

5. Insurance Companies

a. Would the imposition of a state payroll tax on insurance companies impact the retaliatory tax?

6. Other legal/policy issues that arise in the course of the Commission's deliberations

While my Report responds to the issues posed, ${ }^{3}$ it does so in a different order.

\section{Overview}

The Legislature created a Payroll Commission (Commission) ${ }^{4}$ to study the viability of a payroll tax. Hopefully, this Report provides useful background information and analysis to help the Commission identify fundamental policy and design issues that need resolution. The Conclusion to the Report sets forth these issues in a systematic fashion.

\footnotetext{
${ }^{3}$ The one exception has been explained above. See id.

${ }^{4}$ Public Act 19-117; Section 385.
} 
One of the threshold questions for the Commission is whether it would be more cautious to make the tax elective, at least in the short-term, which is what New York did. In April 2018, New York adopted an elective payroll tax, known as the Employer Compensation Expense Program (ECEP). ${ }^{5}$

The ECEP is phased-in over a three-year period. The rates increase from $1.5 \%$ of employee wages in 2019 to $5 \%$ in fiscal year 2021. New York estimates around 312 employers, approximately $0.1 \%$ of employers, ${ }^{6}$ will have opted into the program by December 2019. ${ }^{7}$ Anecdotally, it is believed these are primarily small partnerships. Currently, none of the major employers, including New York State, has opted in.

This Report labors under two major constraints. First, no fully fleshed out bill has been approved by the General Assembly's Finance, Revenue and Bonding Committee, nor has either chamber of the General Assembly passed a bill. There is a bill, S. B. $1143,{ }^{8}$ proposing a $5 \%$ payroll tax, but it was drafted as a "placeholder," with many details missing.

Implementing a payroll tax represents a major change to Connecticut's tax code, and the lack of a fully drafted bill hobbles what can be said with any certainty. There are simply too many moving parts, many of which are interdependent. Many questions need to be answered and refined in order to adopt a fully functioning statute-or at least one

\footnotetext{
${ }^{5}$ Intentionally or not, New York was right in eliminating the term "payroll tax" from the name of its legislation. More about this in the Conclusion.

${ }^{6} \mathrm{https}$ ://www.wsj.com/articles/few-n-y-businesses-sign-up-for-state-program-tobypass-trump-tax-limits-1543766400.

7 James Nani, NY's Payroll Tax Workaround Effort Draws 50 More Businesses, Law 360, December 10, 2019.

${ }^{8}$ S.B. 1143, An Act Establishing a Payroll Tax. This bill seems loosely modeled after New York's Employer Compensation Expense Program (ECEP).
} 
that provides enough guidance to the Department of Revenue Services ("DRS") for the drafting of regulations and other forms of guidance to taxpayers. The Commission confronts a formidable challenge.

Second, a tax modeling consultant ("Consultant") who can work with large data and who would have access to DRS data is necessary to provide critical quantitative analysis of a payroll tax under various assumptions and simulations. The data would be decisive in moving forward with the Commission's deliberations but was not available at the time of this Report. ${ }^{9}$

In preparing this Report, I have talked off the record with numerous experienced and sophisticated persons, in both the private and public sectors. The opinions below are obviously mine alone.

\section{The Concept of a Payroll Tax}

\section{A. Policy Rationale}

The proposal ${ }^{10}$ calls for the imposition of a $5 \%$ payroll tax on wages paid by an employer to its employees for services provided in Connecticut

\footnotetext{
${ }^{9}$ The Connecticut School Finance Project ("Project") has done remarkable simulations of a payroll tax, but has been limited by working with only publicly available data. The Project deserves much credit for identifying the areas that require more rarified and stratified data of the type to which the Consultant would have access.
}

As of December 2019, the Connecticut School Finance Project changed its name to The School and State Finance Project.

In the interest of disclosure, the very able Director of the Project, Katie Roy, won the Morris Pomp Award at UConn Law School. I established this in memory of my father, and it is awarded to the graduate with the highest grade in his or her tax courses.

10 "Proposal" refers to Senate Bill 1143 as interpreted by the DRS and the Office of Policy and Management. 
(Connecticut wages). ${ }^{11}$ In exchange for this tax on the employer, the existing rates in the Connecticut personal income tax rate would each be reduced by 5 points. ${ }^{12}$ If that were all there was to the proposal, it would be nothing more than a proposal to shift the tax burden from individuals with Connecticut wages to their employers. If that were really the goal, there are simpler ways of achieving it. But it is reasonable to assume that few in the Legislature would endorse a tax on Connecticut wages, which might discourage employment in the State, even if the resulting revenue would be used to finance a reduction in the personal income tax on Connecticut wages.

Instead, the anticipated response is that employers would shift the burden of the $5 \%$ payroll tax to their employees by reducing their Connecticut wages by the cost of the tax. ${ }^{13}$ Why would employees accept a reduction in their Connecticut wages? For reasons that will be

${ }^{11}$ A payroll tax might reinforce the current incentive for an employer to characterize service providers as independent contractors rather than employees. Employers have this incentive because of the savings that accrue from not having to include independent contractors in their pension plans and health insurance plans. Employers also do not have to pay FICA taxes for independent contractors. (For an explanation of FICA taxes, see infra Section III.I). The characterization of service providers has become especially relevant in the gig economy and California has recently adopted legislation governing the issue. See California Assembly Bill 5 (AB5). Proper worker classification is an active audit issue in Connecticut.

A payroll tax also reinforces the current incentive to pay workers "off the books." The refundable low-income credit, see Section III.M, might encourage some workers to surface and be paid on the books.

Whether a payroll tax would greatly aggravate either of these two preexisting problems is an unknown empirical question.

12 Under one proposal, some of rates would be reduced by less than 5 points. ${ }^{13}$ The "cost" of the $5 \%$ payroll tax is not identical to $5 \%$, but something less. See infra note 44. 
explained below, ${ }^{14}$ employees would be better off, at least in the shortterm, with lowered wages and a rate reduction. This trade off would lead to higher take-home pay. That higher take-home pay results from reduced federal income taxes and reduced FICA taxes. Longer term effects may be more problematic for certain employees. ${ }^{15}$

The rub is that employees would be better off with reduced wages only if they would not otherwise receive the benefits of the state income tax rate reductions. Put differently, the reduction in wages is the price paid for receiving the offsetting benefits of reducing rates.

\section{B. Who Should Benefit from Reducing Rates?}

One policy decision is whether the state income tax reduction should be eliminated across the board for all wages, regardless of whether the wages were reduced. The correct policy answer would seem to be to limit the benefit of a rate reduction only to employees whose wages were reduced because the employer shifted the payroll tax to them. Without this requirement of a tie-in, employees could be viewed as receiving a windfall: a reduction in their Connecticut personal income taxes without their wages being reduced.

The challenge for the Commission is how to limit the benefits of a tax reduction to only wages that were reduced. In other words, how do we assure that the benefits of a reduction in the rates are tied-in to a reduction in wages?

One difficulty is that many ways exist for an employer to reduce wages and some of these may not be transparent. A tie-in approach could be difficult to administer without some evidence from the employer or

\footnotetext{
${ }^{14}$ See infra Sections III.G, $\mathrm{H}$.

${ }^{15}$ See infra Section V.3.
} 
employees that wages were indeed reduced in one form or another. And could the DRS verify that evidence? Despite the administrative challenges, a tie-in eliminates many problems, some of which are discussed below, so it is worth considerable further analysis of this issue in collaboration with the DRS. ${ }^{16}$

On the other hand, suppose the assumption is that employers are very able to reduce their costs in general-and will do so specifically in the case of the payroll tax. Under this assumption, wages will be reduced and thus there is no need for a tie-in.

Certainly, the assumption that all wages subject to the payroll tax will be reduced simplifies the analysis because it means that the payroll tax is working as intended. If that assumption is challenged, however, and a tie-in proves unworkable, the next possible approach would be to extend the benefits of the tax reduction to all Connecticut wages that were subject to the payroll tax, whether they were reduced or not. This would require the employer to report an employee's Connecticut wages and non-Connecticut wages to the DRS; the former would benefit from the tax reduction, the latter would not. If that proves to be too administratively onerous in the case of a multistate corporation, the benefits from income tax reduction could be extended to all wages, and not limited to only Connecticut wages.

The latter approach eliminates a possible constitutional attack. If nonConnecticut wages are treated more harshly than Connecticut wages by not receiving the benefits of a rate reduction, and there is no acceptable reason for doing that other than administrative

${ }^{16}$ See especially Section V.2. 
convenience, a taxpayer could raise a constitutional argument that interstate commerce was being discriminated against. ${ }^{17}$

A tie-in would help blunt this constitutional argument without the need to grant the benefits of a tax reduction to all Connecticut wages. With a tie-in, non-Connecticut wages would not be discriminated against based on their geographical status but rather because they were not reduced. This is one of the many cases in which a tie-in can play a significant role.

If no tie-in exists, and if little revenue loss results between extending the rate reduction to all wages and extending it for only Connecticut wages, the more cautious approach would be to extend the benefits of a rate reduction to all wages. ${ }^{18}$ On the other hand, if extending these benefits to all wages meant a substantial revenue loss, the constitutional issue will need to be analyzed in depth.

\section{No Rate Reduction should be Extended to Non-Wage Income}

Unjustified by the logic of the payroll tax would be reducing the rate of tax on non-wages such as dividends, capital gains, interest, rent and the like. These items of income would not trigger the $5 \%$ payroll tax. These items could not be reduced by the employer, which would not have any control over them. Different ways exist for limiting the benefits of a rate reduction to only wages, and the DRS should be consulted to determine what is most feasible from its perspective.

\footnotetext{
${ }^{17}$ The Consultant could determine the revenue loss at stake between extending the elimination of the $5 \%$ rate to all wages and limiting it to just Connecticut wages.

${ }^{18}$ These wages would include services performed outside Connecticut. Those wages might not be subject to the payroll tax. See infra note 21 and accompanying text.
} 
In determining the proper rate at which these non-wage items would be taxed, an individual's total income should be considered. In other words, the rate should reflect an individual's ability to pay, measured by her total income. For example, someone with high wages should be taxed on her non-wage income at a higher rate than someone with low wages.

Connecticut uses this approach in determining the income tax payable by nonresidents. Although nonresidents are taxed on only income attributable to Connecticut, the rate at which that income is taxed is determined by their entire income, including income attributable to other states. This same sort of approach should be used in taxing nonwage income.

\section{Should the Base of the Payroll Tax be Tied to the Existing Withholding Tax on Wages?}

Imposing the 5\% rate on all wages rather than on just Connecticut wages would have an administrative advantage of tying the base of the payroll tax to the existing withholding tax on wages. ${ }^{19}$ That is, an easy administrative rule would be that any wages on which the employer already withholds the Connecticut personal income tax would be subject to the $5 \%$ payroll tax.

Current law provides that anyone who maintains an office or transacts business in Connecticut and is considered an employer for federal withholding purposes must withhold the Connecticut income tax whether or not the payroll department is located in Connecticut. In general, all amounts that are wages and subject to federal withholding

\footnotetext{
${ }^{19}$ Although commonly referred to as the "withholding tax," withholding is not a tax but rather a means of collecting a tax already owed by the recipient of the income that is being withheld upon.
} 
are also wages for Connecticut income tax withholding purposes. These amounts include, but are not limited to, fringe benefits, supplemental compensation, golden parachutes, sick pay, moving expenses, restricted stock income, stock options, non-compete income, deferred compensation, and severance pay. ${ }^{20}$

In the case of residents, withholding applies to all their wages, even if the resident works outside of Connecticut. Because withholding already exists in this situation, it is tempting to include wages for services performed outside Connecticut in the base of the payroll tax, especially if that would generate significant revenue. Administratively, that might seem attractive in the case of a Connecticut-based corporation with employees performing services in and outside the State.

Administratively attractive or not, extending the reach of the payroll tax to out-of-state wages would be constitutionally suspect. ${ }^{21}$

Unfortunately, if the tax were applied to only Connecticut wages, the

${ }^{20}$ Public Act 18-49, Sec. 20(2)(C) provides that for purposes of determining the compensation derived from or connected with sources within Connecticut, nonresident individuals shall include income from days worked outside Connecticut for their personal convenience and not for that of their Connecticut employer, if their state of domicile uses a similar test. Delaware, Nebraska, Pennsylvania, and most importantly New York, use a similar "convenience of the employer" test.

${ }^{21}$ Under the Commerce Clause, taxes have to be "fairly apportioned." See Complete Auto Transit, Inc. v. Brady, 430 U.S. 274 (1977), Container Corp. of Am. v. Franchise Tax Bd., 463 U.S. 159. This constitutional mandate applies even to a Connecticut-based corporation with a modest out-of-state presence. By analogy, a tax on all of the income of a Connecticut employer, regardless of where generated, would violate the fair apportionment requirement, making a tax on all of the payroll of a Connecticut employer equally suspect. 
link between the payroll tax and withholding on Connecticut residents would be severed. ${ }^{22}$

On the other hand, the link remains intact in the case of nonresidents. Wages of nonresidents are subject to Connecticut income tax withholding if the wages are paid for services rendered in Connecticut. Here it is more feasible and easier for both the DRS and employers to administer the payroll tax if it covers the wages of nonresidents who are subject to income tax withholding.

For administrative convenience, a special rule applies that treats a nonresident employee who performs personal services for employment purposes in Connecticut for 15 days or less as not subject to Connecticut income taxation on those wages and consequently not subject to withholding. ${ }^{23}$ That rule could obviously be relaxed for the payroll tax but at the price of administrative complexity.

The 15-day rule is just one of the special rules that limit the reach of the State's personal taxing jurisdiction; other rules apply to limited situations. ${ }^{24}$ If these rules were to apply to the payroll tax so that some

\footnotetext{
22 The Consultant could determine the extent of wages paid for services performed out-of-state.
}

${ }^{23}$ If a nonresident employee who was reasonably expected to work 15 or fewer days in Connecticut during a calendar year actually works more than 15 days in Connecticut during such year, the employer must withhold on all the compensation paid to that nonresident employee for services performed in Connecticut, including the compensation paid for the first 15 days.

${ }^{24}$ For example, compensation paid by interstate rail carriers, interstate motor carriers, and interstate motor private carriers to a nonresident employee who performs regularly assigned duties in two or more states including Connecticut is not subject to the State's income tax and thus no withholding applies. Compensation paid by an interstate air carrier to a nonresident employee who performs regularly assigned duties on an aircraft in two or more states is considered to be income derived from sources in both the employee's state of 
Connecticut wages were outside the base of the tax, some revenue would be lost. The Consultant would need to determine the amount lost and whether the rules need to be relaxed or not, but any revenue gained would come at the price of increased administrative complexity.

\section{E. Expected Reduction in Wages}

Employers are expected to shift the cost of the payroll tax to employees by reducing their wages. ${ }^{25}$ In this manner, employers are held harmless from the payroll tax. ${ }^{26}$ Because this reduction in wages would implicitly be a proxy for employees paying a 5\% personal income tax, the State would reduce existing rates by 5 points. Otherwise, the same wages

residence and the state in which the employee earns more than $50 \%$ of the compensation. An employee is considered as earning more than $50 \%$ of the compensation in Connecticut if the scheduled flight time in Connecticut is more than $50 \%$ of the total scheduled flight time in the calendar year. Other special rules apply to seaman's wages and military personnel. For a readable presentation of the extensive rules, upon which my description is based, see Connecticut Employer's Tax Guide, https://portal.ct.gov//media/DRS/Publications/pubsip/2019/IP-2019(1).pdf?la=en.

${ }^{25}$ This does not mean reducing wages by the full $5 \%$. The cost of the payroll tax is not equal to the $5 \%$. See infra note 44 .

The wages of an employee whose services would be performed entirely in Connecticut could be reduced starting at the time the payroll tax became effective. Employees who perform only some of their services in Connecticut in an unpredictable manner because of their travel schedules create a unique situation. It would only be after the fact that their Connecticut wages could be identified. In other words, they may have a fixed salary for the year regardless of where they work, but the services they perform in Connecticut may be variable and unknown ex ante. This problem is less severe if the time spent in Connecticut does not vary significantly from year-to-year.

${ }^{26}$ As will be discussed, the employer will actually come out ahead by at least saving the FICA taxes that would have otherwise been paid on the higher wages. See infra Section III.G. 
would be taxed twice; first, implicitly as employers reduced wages to shift the payroll tax to the employee, and again, when those reduced wages became subject to the pre-existing income tax rates.

To summarize, if the payroll tax works as intended, the State swaps a $5 \%$ payroll tax for a reduction in rates, and employers pass the cost of the payroll tax onto employees through a concomitant wage reduction. Focusing only on the Connecticut personal income tax, an employee breaks even: the wage reduction would be offset by the income tax savings from reducing rates. Once the federal personal income tax and FICA taxes are taken into account, however, the employee comes out ahead, as does the employer.

The rationale of the payroll tax assumes a tie-in. In sharp contrast, if employees were to benefit from the rate reduction without any reduction in wages, they would receive a windfall, ${ }^{27}$ and State revenue would be needlessly lost.

If employers cannot shift the tax onto employees, the employers will bear the cost of the tax. Then the payroll tax would become an added cost for employers, and even worse, send the message that Connecticut is anti-jobs. If the payroll tax transmorphs from a proxy for an income tax, intended to fall on Connecticut employees through wage reductions, to a tax on the employer, what would the effect be on jobs? Would the tax constrain employment? Would employers pass the tax backward to vendors, suppliers, and independent contractors? Would employers pass the tax forward to consumers? Would Connecticut be seen as anti-jobs? Would the tax add to Connecticut's reputation as a high tax state?

${ }^{27}$ See supra Section III.B. 
With no tie-in, the benefit of a rate reduction would be bestowed on employees whose wages would not be reduced. Would that offset the above concerns and demonstrate that Connecticut was not anti-jobs? Would that tax cut encourage persons to seek employment in the State ${ }^{28}$ These are critical but difficult empirical questions.

It bears repeating that the belief that wages would be reduced to offset the cost of the payroll tax to employers is central to the rationale of the payroll tax. If that does not happen, the whole reason for having a payroll tax is undermined.

\section{F. The Payroll Tax as a Response to the Federal Cap on Itemized Deductions}

The initial impetus for the payroll tax was presumably the changes implemented by the so-called 2017 Tax Cuts and Jobs Act ("Act"). ${ }^{29}$ The Act imposed the now infamous $\$ 10,000$ cap on the federal itemized deduction for state and local taxes under the Internal Revenue Code. The cap is scheduled to expire on December 31, 2025.

The Connecticut School Finance Project ("Project"), known today as The School and State Finance Project, deserves the credit for proposing a payroll tax as one way of responding to the cap.

\footnotetext{
${ }^{28}$ For the reasons discussed in the text accompanying supra note 18 , the benefits of eliminating the $5 \%$ rate probably cannot be limited to just those working in Connecticut without raising the possibility of a constitutional issue. Revenue considerations might require revisiting the constitutional issue in some depth. ${ }^{29}$ The Tax Cuts and Jobs Act was the original name of the bill. Because of a ruling by the Senate parliamentarian, the actual name is "An Act to provide for reconciliation pursuant to titles II and $\mathrm{V}$ of the concurrent resolution on the budget for fiscal year 2018."
} 
The State has challenged the legality of this cap in a case currently before the Second Circuit Court of Appeals. ${ }^{30}$ Even before the outcome of this litigation, the 2020 election may result in eliminating the cap, which the Democrats have made a priority. ${ }^{31}$

Prior to the cap, taxpayers who itemized rather than taking the standard deduction on their federal income tax returns could deduct an unlimited amount of their state and local taxes, which in turn would reduce their federal income taxes..$^{32}$ Connecticut has a disproportionate number of itemizers with large SALT deductions. The cap thus has had a substantial negative impact on Connecticut residents. ${ }^{33}$ DRS estimated that the cap would affect 170,000 residents by reducing their SALT itemized deduction by $\$ 10.3$ billion, increasing their federal taxes by

\footnotetext{
${ }^{30}$ New York v. Mnuchin, ___F. Supp. 3d__, 2019 WL 4805709 (S.D.N.Y. 2019), appeal docketed, No. 19-3962 (2d Cir. Nov. 26, 2019).

${ }^{31}$ Representatives Thomas Suozzi, D-N.Y, Bill Pascrell, D-N.J., and Mike Thompson, D-Calif., have recently proposed the "Restoring Tax Fairness for States and Localities Act." This bill increases the cap to $\$ 20,000$ for married taxpayers who file jointly in 2019, and phases it out over 2020 and 2021. The Bill would also raise the top rate of the federal personal income tax to $39.6 \%$. The Bill was passed by the House on December 20, 2019 by a vote of 218-206. The President has threatened to veto the Bill in the unlikely event it passes the Senate. Brittany De Lea, Trump SALT Cap Veto Threat Doesn't Deter Democrats, Fox Business (Dec. 20, 2019), https://www.foxbusiness.com/money/trump-veto-democrat-salt-capbill.

32 Because the starting point for determining the Connecticut income tax is federal adjusted gross income, the federal election to itemize rather than take the standard deduction, which reduces federal taxable income but not federal adjusted income, has no effect on a taxpayer's Connecticut income taxes. ${ }^{33}$ The cap was just one part of sweeping changes made in 2017 and some Connecticut taxpayers had a reduction in their federal income taxes despite the cap.
} 
$\$ 2.8$ billion. ${ }^{34}$ If employers are able to shift the cost of the payroll tax to employees, with the concomitant reduction in their federal income and FICA taxes, the resulting tax savings will offset the effect of the cap.

${ }^{34}$ https://www.ctcpas.org/Content/Files/Pdfs/OLR2018Report.pdf. This is the most recent data available. The $\$ 2.8$ billion figure comes from Steve Wamhoff et al., A Fair Way to Limit Tax Deductions, Institute on Taxation and Economic Policy (ITEP), (Nov. 14, 2018), https://itep.org/a-fair-way-to-limit-tax-deductions/. In the interest of disclosure, I am on the Board of ITEP and the former President. The Board does not approve any publications by the staff and those publications do not necessarily represent the views of the Board.

About $8.4 \%$ of Connecticut taxpayers experienced a tax increase from the Act. Frank Sammartino, et al., The Effect of the TCJA Individual Income Tax Provisions Across Income Groups and Across the States, Tax Policy Center (Mar. 28, 2018), http://www.taxpolicycenter.org/sites/default/files/publication/154006/the effec $\mathrm{t}$ of the tcja individual income tax provisions across income groups and ac ross the states.pdf.

The payroll tax was one part of the State's responses to the cap. Another response was a new entity-level income tax on most pass-through businesses. PA 18-49, §§ 1-8. Connecticut was the first state to adopt this approach in 2018 and is still the only state where this approach is mandatory. This pass-through entity tax is levied at the top Connecticut personal income tax rate of $6.99 \%$ and offset by a State personal or corporation income tax credit for the entity's members. Businesses can claim this tax as a deductible expense against their federal taxes and pass the benefit of the deduction to their members. The IRS has not opined on the legitimacy of the entity-level tax.

Another response was that the Legislature allowed municipalities to provide a property tax credit to eligible taxpayers who make voluntary payments to a municipally approved nonprofit that is organized exclusively to support municipal spending on programs and services (i.e., community supporting organizations). PA 18-49, § 10. The goal was to allow taxpayers who make these payments to claim a federal charitable contribution deduction for the donation to the nonprofit, in effect to substitute an uncapped charitable contribution for a capped property tax deduction. Perhaps unsurprisingly, the Internal Revenue Service has issued regulations to thwart this strategy. The State has challenged 
The Act also increased the standard deduction, which is an alternative to the itemized deductions. This increase in the standard deduction resulted in fewer taxpayers being subject to the cap; the ones that continue to itemize tend to be higher-income individuals. ${ }^{35}$

As will be seen shortly, any reduction in wages reduces federal taxes for both employees and employers independent of whether a cap exists or not. ${ }^{36}$ Because of these federal tax consequence, debate over a payroll tax should not be tied to that of the cap. Even if the cap were eliminated, the proposal for a payroll tax has merits on its own because of the reduction in federal taxes for both employees and employers. And despite the cap being scheduled to expire on December 31, 2025, no guarantees exist that this will happen.

\section{G. Employers' Response to a Payroll Tax}

As already suggested, employers can respond to the payroll tax along a continuum marked by two polar points.

The only response consistent with the rationale of the payroll tax would be for an employer to pass the cost of the tax onto employees by reducing their wages. If this occurs, the effect would be like that of a $5 \%$ State income tax. In a sense, the payroll tax would function as a proxy for a State income tax by reducing wages, just like what an income tax would do, but in this case the reduction would occur through employers shifting the cost of the payroll tax onto employees.

these regulations. State of New Jersey et al v. Mnuchin et al, No. 1:19-cv-06642 (S.D.N.Y., filed July 17, 2019).

35 No publicly available data exist on the effect the increased standard deduction had on reducing the number of itemizers in the State. The Consultant should be able to provide this data.

${ }^{36}$ See Section III.H. 
In other words, the reduction in the after-tax amount of wages that would otherwise occur explicitly under the State's existing income tax rates would now occur implicitly through a reduction in wages attributable to the payroll tax. The existing rates in the Connecticut personal income tax would each be reduced by five points to eliminate taxing these same wages a second time.

For simplicity, assume a single individual with $\$ 10,000$ of wages paid a $5 \%$ tax -- $\$ 500--$ on these wages, leaving the taxpayer with $\$ 9,500$. After the adoption of a $5 \%$ payroll tax, these wages would be reduced by $\$ 500$, to $\$ 9,500$ and the $5 \%$ personal income on these wages would be eliminated.

Assuming wages were reduced as in this example, three major consequences would follow. First, an employee's federal income tax would be reduced. Second, reduced wages would mean lower FICA taxes (Social Security and Medicare taxes). ${ }^{37}$ Consequently, a payroll tax would increase an employee's take-home pay at the expense of the federal fisc, ${ }^{38}$ which is part of its State charm. Somewhat counterintuitively, even though wages are reduced, the combination of State income tax savings and the federal income and FICA tax savings means the employee is actually better off and will end up with more takehome pay.

${ }^{37}$ FICA taxes are described in detail in Section III.I. FICA is a tax based on wages and imposed on both employers and employees. FICA funds Social Security and Medicare benefits. Consequently, reducing FICA taxes is not an unmitigated benefit for employees because Social Security benefits are based in part on the aggregate amount of FICA taxes paid. (Medicare benefits are not based on wages.) Other contractual forms of retirement benefits are also based on wages. ${ }^{38}$ It might seem that employers would benefit from the reduction in wages, but that benefit would be offset by the payroll tax they would pay. See infra notes 5354 and accompanying text. 
A third consequence is that an employer would also pay less FICA taxes because of the lower wages, and perhaps make less contributions to pension plans if these were based on wages. Reduced FICA taxes would be an advantage for the employer but not necessarily in the long-term for the employee, ${ }^{39}$ although some employers might want to use part of their FICA savings to offset the future loss in retirement benefits.

These consequences occur if employers are able to reduce wages by the cost of the payroll tax. If, however, employers could not reduce wages, the payroll tax would become an explicit tax on employers and not an implicit tax on employees. No reduction in FICA taxes would result. Wage earners, however, would nonetheless benefit from the reduction in rates in the personal income tax, essentially receiving a windfall with the State needlessly giving up revenue.

Put differently, if employers cannot reduce wages, they would be saddled with a new $5 \%$ tax. If there were no tie-in and the benefits of reducing rates were available whether wages were reduced or not, ${ }^{40}$ employees would benefit, and employers would lose. The payroll tax would result in a major shift in the Connecticut income tax from employees to employers.

\section{H. Illustrative Examples}

\section{Effect on an Employee}

To make the above discussion more concrete, consider a Connecticut employer having a resident employee. Assume the employee is single and has $\$ 80,000$ of Connecticut adjusted gross income (AGI) attributed solely to Connecticut wages. The employee is currently subject to a

\footnotetext{
${ }^{39}$ See Section V.3.

${ }^{40}$ See Section III.B.
} 
Connecticut income tax of $\$ 4,050^{41}$ and federal taxes (personal income tax plus FICA taxes) of $\$ 17,020 .{ }^{42}$ The employee takes home $\$ 58,930$ $(\$ 80,000-\$ 4,050-\$ 17,020)$ after State and federal taxes. I will refer to this as the pre-payroll tax benchmark ("benchmark").

Assume a new $5 \%$ payroll tax were adopted and rates in the personal income tax were reduced by five points with no tie-in. Two opposite alternatives are possible.

If the employer could not reduce Connecticut wages to offset the amount of the new tax, the payroll tax effectively becomes a new 5\% tax on the payment of its Connecticut wages. The employer would pay a payroll tax of $\$ 4,000(5 \% \times \$ 80,000)$.

Without a tie-in, the employee would nonetheless receive the benefit of the rate reduction on Connecticut wages. The employee can be viewed as getting a windfall because she received a tax benefit and did not suffer any reduction in wages. The effect is that the $5 \%$ payroll tax on Connecticut wages, intended to substitute for the pre-existing $5 \%$ rate on those wages, simply becomes a tax on Connecticut employers and a tax reduction for Connecticut employees.

The Connecticut employee would no longer pay the former State income tax of $\$ 4,050$, which is assumed to have been eliminated. She

${ }^{41}$ See the 2018 Income Tax Tables accompanying the 2018 Form CT-1040 Booklet. The taxpayer's effective tax rate is $5.0625 \%(\$ 4,050 / \$ 80,000)$. I am using 2018 rates to conform with the examples used by the Project.

${ }^{42}$ For the convenience of the reader, the calculations in this example are based on the Project's excellent “FAQs: Proposal To Shift A Portion Of CT's Income Tax To A Payroll Tax, July 30, 2019, p.2. The Project assumed the taxpayer claims the standard deduction and does not itemize, which is the only assumption it could make without access to actual returns. The Consultant should have access to actual Connecticut income tax returns and refine the examples used throughout the text. 
would continue to pay the federal tax of $\$ 17,020^{43}$ and thus clears $\$ 62,980(\$ 80,000-\$ 17,020)$. Her take-home pay increases by $\$ 4,050$ $(\$ 62,980-\$ 58,930)$, which is the amount of the State's personal income tax that she no longer would have to pay even though her wages were not reduced. This is her optimal tax position: no State personal income tax and no reduction in her wages. None of the other alternatives below can provide a better tax result. This optimal tax position results because there was no tie-in. For example, with a tie-in, she would not get the benefit of eliminating the personal income tax and her take home pay would remain at $\$ 58,930$.

At the other extreme, assume the employer can reduce wages by the amount of the payroll tax. Whether there is a tie-in or not would now be irrelevant because in either event the employee would receive the benefit of the reduction in the State's personal income tax.

Assume the employer would reduce her Connecticut wages by $5 \%$ to $\$ 76,000(\$ 80,000-[5 \% \times \$ 80,000]) .{ }^{44}$ Eliminating the State's personal

${ }^{43}$ Because of the assumption that the taxpayer claimed the standard deduction and did not itemize her state taxes, her federal income tax will remain the same regardless of the amount of her Connecticut income tax.

${ }^{44}$ The wages actually would have to be reduced to slightly less than $\$ 4,000$. Wages have to be reduced to the point where the savings from the reduction in wages is equal to the $5 \%$ tax on the new, lowered wages. Under this assumption, the employer would reduce wages by $\$ 3,810(\$ 80,000 / 1.05)$ to $\$ 76,190$. By reducing the wages to $\$ 76,190$, the payroll tax on the employer would be $\$ 3,810$ $(5 \% \times \$ 76,190)$, equal to the $\$ 3,810$ the employer saved by reducing the wages to $\$ 76,190(\$ 80,000-\$ 76,190=\$ 3,810)$. I have generally not incorporated this subtlety into the examples in the text in order to conform them to the Project's examples, which ignore this complication. But see infra note 53 where this refinement is taken into account.

Employers using the payroll tax as a fig leaf to reduce wages by the greatest amount feasible might also conveniently ignore this subtlety. 
income tax on her wages ${ }^{45}$ produces a savings of $\$ 4,050$, the amount that was previously paid in Connecticut income tax.

The payroll tax now functions as an implicit income tax because the employee has borne the full amount of the payroll tax, as if it were an income tax. Because her wages would have been reduced by only $\$ 4,000$, and she would save $\$ 4,050$ in State tax, she comes out ahead by $\$ 50 .{ }^{46}$

I have purposely picked a situation where the savings in State taxes closely approximates the reduction in wages in order to isolate the Connecticut tax impact from the federal tax impact. Because the employee would break even at the State level, that is, the reduction in wages would be offset by the Connecticut personal income tax savings, any reduction in federal taxes would be a net benefit.

That benefit can be calculated as follows. The employee's $\$ 4,000$ reduction in wages would reduce her federal tax. The federal tax (income and $\mathrm{FICA}^{47}$ ) on the lower wages would be $\$ 15,834$. The employee would now clear $\$ 60,166(\$ 76,000-\$ 15,834)$. Her take-home pay would increase by $\$ 1,236$ over the benchmark $(\$ 60,166-\$ 58,930)$.

\footnotetext{
${ }^{45}$ There could be some State income tax depending on the new rate schedule accompanying the payroll tax. See infra note 70 and accompanying rate schedule. The Consultant should be in a position to simulate various Connecticut rate schedules that could apply in coordination with whatever level of payroll tax is eventually determined.

${ }^{46}$ I intentionally picked a scenario where the employee essentially breaks even. Working with DRS data, the Consultant would undoubtedly produce an exhaustive list of possible outcomes under various assumptions. Working with only publicly available data, the Project has also generated an illustrative chart of outcomes, assuming a flat payroll tax rate of $5 \%$ and a progressive rate schedule on wages ranging from $.50 \%$ to $2.99 \%$. See supra note 42 at p.3.

${ }^{47}$ The 2020 changes in FICA, see Section III.I are ignored in the calculations in the Report, which are all based on 2019 law.
} 
Even though her wages are reduced, the tax savings would be in excess of that reduction and the taxpayer would come out ahead. But if measured against her take home if her wages were not reduced and there was no tie-in, she has $\$ 2,814$ less in take home $(\$ 60,166$ $\$ 62,980)$. Without a tie-in, she would get the benefit of the reduction in State income taxes despite having no reduction in her wages.

The following Table summarizes the above results.

\begin{tabular}{|l|l|l|l|l|}
\hline Benchmark & $\frac{\text { CT AGI }}{\$ 80,000}$ & $\frac{\text { CT Inc. Tax }}{\$ 4050}$ & $\frac{\text { Fed Taxes }}{\$ 17,020}$ & $\frac{\text { Take Home }}{\$ 58,930}$ \\
\hline $\begin{array}{l}\text { Payroll Tax, No } \\
\text { Reduction in } \\
\text { Wages, No Tie in }\end{array}$ & $\$ 80,000$ & - & $\$ 17,020$ & $\$ 62,980$ \\
\hline $\begin{array}{l}\text { Payroll Tax, } \\
\text { Reduction in } \\
\text { Wages (Tie In } \\
\text { Irrelevant) }\end{array}$ & $\$ 76,000$ & - & $\$ 15,834$ & $\$ 60,166$ \\
\hline
\end{tabular}

Predictably, the best tax position in the Table--\$62,980--results from receiving the benefits of a reduction in the Connecticut income tax with no reduction in wages. However, if employers can reduce wages by the cost of the payroll tax, then the combination of the benefits from reducing the State income tax and the reduction in federal personal income taxes and FICA taxes, will increase the individual's take home to $\$ 60,166$, which is greater than the benchmark, but not in excess of the optimal take-home pay of $\$ 62,980$.

Note the importance of the tie-in if wages were not reduced. With a tie-in, an employee would receive no reduction in State income taxes and her take home would remain unchanged at $\$ 58,930$. Without a tiein, the employee receives a windfall, and her take home increases to $\$ 62,980$. 
The Project has provided simulations for other taxpayers, all of which assume a reduction in salary of $5 \%$. Whether there is a tie-in or not is irrelevant under that assumption and not analyzed by the Project.

As another illustration, consider that before the adoption of a payroll tax, a married couple taking the standard deduction earning $\$ 200,000$ in Connecticut wages would pay $\$ 10,500$ in Connecticut income taxes and $\$ 42,823$ in federal taxes, clearing $\$ 146,677$ (\$200,000-\$10,500$\$ 42,823)$. If their wages were reduced by the $5 \%$ payroll tax, their Connecticut AGI would be reduced to $\$ 190,000,{ }^{48}$ and their federal taxes would be reduced to $\$ 40,278$. For simplicity, assume they would pay no Connecticut income tax going forward on their reduced wages ${ }^{49}$ because of the five-point reduction in the brackets. They would now clear $\$ 149,722$ (\$190,000-\$40,278), for an increase in their take-home pay of $\$ 3,045(\$ 149,722-\$ 146,677) .{ }^{50}$ The reduction in wages of $\$ 10,000$ is more than offset by the $\$ 13,045$ reduction in aggregate taxes. (A reduction of $\$ 10,500$ in the State income tax, and a savings of $\$ 2,545$ in the federal taxes, ${ }^{51}$ generates a total federal and State savings

\footnotetext{
${ }^{48}$ This assumes a $5 \%$ reduction in wages rather than a slightly less reduction. See supra note 44.

${ }^{49}$ This would depend on the any new personal income tax rate schedule that was adopted with the payroll tax. Under the rate schedule accompanying infra note 70 , they would be in the $1 \%$ bracket.

${ }^{50} \mathrm{I}$ assume no Connecticut income tax post-payroll tax in order to maximize the amount of the increase in their tax-home pay. I do this in order to identify the amount that would be available to be shared with the State. The Project calculates the new Connecticut income tax using the rate structure put forth in the Act establishing the Commission. See infra note 70 and accompanying rate schedule. Also, the Project assumes wages are reduced by $5 \%$ whereas I would use a slightly different calculation. See supra note 44 .

$51 \$ 42,823-\$ 40,278=\$ 2,545$.
} 
of $\$ 13,045 .^{52}$ The savings are $\$ 3,045$ greater than the reduction in wages $(\$ 13,045-\$ 10,000=\$ 3,045))$.

\section{Effect on Employer}

Assuming the employer could reduce an employee's Connecticut wages to offset the payroll tax, its state and federal corporate income taxes would remain the same. To illustrate, instead of deducting in the prior example $\$ 80,000$ in wages prior to the payroll tax, it would continue to deduct that same total amount, but that would now consist of a combination of a deduction of wages of $\$ 76,190^{53}$ and a deduction for the payroll tax on those reduced wages of $\$ 3,810^{54}(\$ 76,190+\$ 3810=$ $\$ 80,000)$.

If the employer could not reduce the Connecticut wages and would have to absorb the payroll tax, it would bear a new $5 \%$ tax. This tax would be deductible as a cost of doing business, the same way wages or other costs of business are deductible. The payroll tax would reduce the employer's taxable income under both the federal corporate income tax and the state's corporate income tax.

The employer would be subject to a federal corporate rate of $21 \%$ so that every $\$ 100$ of deductible payroll tax would reduce its federal corporate income tax by $\$ 21$. That reduction would mitigate the impact of the new payroll tax. The $\$ 100$ payroll tax would have a net cost to the employer of $\$ 79$ after considering the reduction in federal taxes.

\footnotetext{
$52 \$ 10,500+\$ 2,545=\$ 13,045$.

${ }^{53}$ For the purpose of this analysis, I have dropped the simplifying assumption that wages would be reduced by $\$ 4,000$ to $\$ 76,000$. See supra note 44 .

${ }^{54} 5 \%$ x $\$ 76,190=\$ 3809.50$
} 
The deduction of the payroll tax would also reduce the State's business tax liability, ${ }^{55}$ which is the greater of the net income base tax and the capital base tax. The capital base tax is calculated by levying a rate of $0.31 \%$ to the apportioned capital base. The tax on the net income base is $7.5 \%$ of apportioned Connecticut net income, with a $10 \%$ surtax for corporations with total income of at least $\$ 100$ million. Other nuances exist. The State's corporate income tax is a function of how much income a corporation apportions to Connecticut. Various apportionment formulas are provided depending on the type of activities in which a corporation engages. These complexities defy straightforward modeling. Presumably, only a small number of corporations pay the bulk of the corporation business tax, and the Consultant should have access to their returns for precise calculations.

\section{Unbundling FICA taxes ${ }^{56}$}

The amount of the individual federal tax in the above examples consists of two different components, which for ease of presentation were bundled together and referred to simply as "federal taxes." The first part is the amount of the federal personal income tax, which would be reported on Form 1040.

Employers and employees, however, also pay taxes under the Federal Insurance Contributions Act ("FICA"). FICA taxes are composed of the old-age, survivors, and disability insurance taxes, commonly known as Social Security taxes, and the hospital insurance tax, commonly known

\footnotetext{
55 This Report assumes the employer is taxable as a C Corporation. Pass-through entities would also be subject to the payroll tax, as would S Corporations. The Consultant would have the ability to sort through these distinctions.

${ }^{56}$ See generally, Understanding Employment Taxes, https://www.irs.gov/businesses/small-businesses-selfemployed/understandingemployment-taxes.
} 
as the Medicare tax. Different rates and rules apply for these taxes. FICA taxes apply to wages, so the lower the wage, the lower the FICA tax. To the extent employers lower wages to pass through the cost of the payroll tax, both the employer's and the employee's FICA taxes will be reduced.

The current tax rate for Social Security is $6.2 \%$ for the employer and $6.2 \%$ for the employee. The current tax rate for Medicare is $1.45 \%$ for the employer and $1.45 \%$ for the employee, or $2.9 \%$ total. Consequently, the combined rate is $7.65 \%(6.2 \%+1.45 \%)$.

The 2020 social security wage base is $\$ 137,700$ (an increase of $\$ 4,800$ from $\$ 132,900$ in 2019). This wage base is the maximum amount of wages that is subject to the tax for that year.

The maximum social security tax employees and employers pay in 2020 is $\$ 8,537.40(6.2 \% \times \$ 137,700)$, an increase of $\$ 297.60$ from the $\$ 8,239.80$ maximum in 2019 . Only the social security tax has a wage base limit $(\$ 137,700)$; the Medicare tax has none.

Not only is the Medicare tax unlimited in amount, but also an additional $0.9 \%$ applies to individuals with annual earned income of more than $\$ 200,000$, and married couples filing jointly with such income of more than $\$ 250,000$. Employers withhold this additional 0.9\% Medicare tax. There is no employer match for this $0.9 \%$ additional Medicare Tax. The combined rate of social security tax and the Medicare Tax can exceed $7.65 \% .^{57}$

57 Connecticut also imposes a State unemployment tax only on employers. The tax is levied on the first $\$ 15,000$ of an employee's wages. The rate varies between $1.9 \%$ and $6.8 \%$ based on the experience an employer has had with the unemployment of its employees. New employers, which have no experience, are subject to a rate of $3.4 \%$. Because it is impossible to talk about this tax in the abstract, and given its relatively low amount, I have ignored it from all 
The employer can deduct the FICA taxes that it collects on behalf of its employees' wages as well as the FICA taxes it pays on its own behalf; these are part of its deductible business expenses. Employees cannot deduct the FICA taxes that their employer collects on their behalf nor can they deduct the FICA taxes that they pay on their own accord.

In the example above of the single employee whose $\$ 80,000$ of wages was reduced by $\$ 4,000$, the employer and employee each saved $7.65 \%$ $x \$ 4,000$, or $\$ 306$ in FICA taxes. That savings was part of the reduction of federal taxes from $\$ 17,020$ to $\$ 15,834$; the rest was the reduction in the federal income tax.

For businesses with large payrolls, the savings in FICA taxes can be significant. The Project created a representative model for Connecticut hospitals, which had 103,000 employees and a $\$ 7.6$ billion payroll; which would have paid FICA taxes of $\$ 581,400,000 .{ }^{58}$ After the imposition of a $5 \%$ payroll tax and a concomitant reduction in wages, payroll would be reduced to $\$ 7.220$ billion, reducing FICA taxes to $\$ 552,330,000$ for a total savings in FICA taxes of $\$ 29,070,000$ $(\$ 581,400,000-\$ 552,330,000)$. The savings in salary would be $\$ 380,000,000$ (\$7.6 billion-\$7.220 billion). The total savings in FICA taxes and salary would be $\$ 409,070,000(\$ 29,070,000+\$ 380,000,000)$. After paying the payroll tax of $\$ 361,000,000$, the hospitals would save $\$ 48,070,000$. Of course, if the hospitals could not reduce their wages

calculations, as has the Project. I have also ignored the federal unemployment tax, as has the Project, whose rate is $6.0 \%$. That tax applies to the first $\$ 7,000$ paid to each employee as wages during the year. In general, if wages were subject to the Connecticut unemployment tax, there would be a credit of up to $5.4 \%$ for that tax against the federal tax.

${ }^{58}$ See https://www.hartforbusiness.com/article/report-ct-hospitals-healthsystems-generate-27b-for-economy. That the hospitals may be non-profit does not excuse them from paying FICA taxes, any more than the State, municipalities, or school boards are excused from paying FICA taxes. 
(or shift the payroll tax backward or forward), their costs would increase by $\$ 361,000,000$, the full amount of the payroll tax.

The discussion above focused on the fiscal impact of the FICA taxes on employers and employees. What follows is a summary of the fiscal impact on Connecticut and on the federal government.

\section{J. Effect on State and Federal Corporate Income Taxes from Reduced FICA Taxes}

An employer deducts the FICA taxes imposed on it and the FICA taxes it collects on behalf of employees. If wages were reduced and FICA taxes were concomitantly reduced, an employer's federal and state corporate income tax would increase because a deduction that it previously had for FICA taxes would now be reduced. That in turn, would increase its taxable income. Nevertheless, the savings from paying less FICA taxes would outweigh the increase in the federal corporate income tax and the state corporate income tax so the net effect would be an overall reduction in federal and state corporate income taxes.

To illustrate, assuming a federal corporate rate of $21 \%$, every $\$ 1,000$ savings in FICA taxes would increase the federal tax by $\$ 210$. The employer would have a net gain of $\$ 790(\$ 1,000-\$ 210) .{ }^{59}$ From the federal government's perspective, the increase in federal corporate income tax of $\$ 210$ would help offset the $\$ 1,000$ reduction in FICA taxes, which are paid into a trust fund, separate from the government's general revenue.

${ }^{59}$ This is the same type of calculation for the payroll tax (or any deduction). 
The State receives none of the FICA taxes, so the reduced payment does not affect its revenue. The State would, however, receive revenue from the new payroll tax.

\section{K. Effect on Connecticut and Federal Revenue from the Payroll Tax}

Whether wages are reduced or not, the payroll tax would be a new source of revenue for the State. It would also be deductible by employers, just like wages. But the State would come out ahead as illustrated below.

If wages were not reduced, the payroll tax would become a net new business deduction. The federal corporate income tax would be reduced by the new deduction and not be offset by any revenue from the State's payroll tax. For example, assuming a federal corporate rate of $21 \%$, every $\$ 1,000$ of deductions for the new Connecticut payroll tax would reduce the federal corporate income tax by $\$ 210$.

The Connecticut corporate income tax would also be reduced, which would offset the amount of revenue from the payroll tax. But overall, the State would come out ahead. To illustrate in the case of an intrastate corporation paying the corporate income tax at a $7.5 \%$ rate, a $\$ 1,000$ payroll tax would reduce the State corporate income tax by $\$ 75$ $(\$ 1,000 \times 7.5 \%)$. The State comes out ahead by $\$ 925(\$ 1,000-\$ 75)$.

If the cost of the payroll tax is fully shifted to employees by reducing their wages, an employer would deduct the same amount as it previously did, ${ }^{60}$ which would have no effect on the federal or the State corporate income tax.

${ }^{60}$ See supra notes 53-54 and accompanying text. 
The reduced wages would, however, would reduce the federal personal income tax and the FICA taxes paid by both the employee and the employer. The federal government comes out a loser.

\section{Minimum-Wage Earners}

The Legislature recently increased the minimum wage in Connecticut from its current level of $\$ 10.10$ to $\$ 11.00$ on October 1, 2019; to $\$ 12.00$ on September 1, 2020; to $\$ 13.00$ on August 1,$2021 ; \$ 14.00$ on July 1 , 2022; and finally, to $\$ 15.00$ on June 1,2023 . An employer cannot unilaterally change these amounts. Accordingly, employers would not be able to reduce wages below these amounts to offset the cost of a payroll tax.

One way of dealing with this constraint would be to exempt the wages of minimum wage employees from the base of the payroll tax. Otherwise, the payroll tax would be a cost of doing business and reduce profits, increase the prices paid to customers, reduce payments to suppliers or independent contractors, or some combination thereof. In extreme cases, a low-profit business with a high number of minimum wage earners could otherwise pay more in the payroll tax than it has in profits.

Minimum-wage earners are unlikely to be above whatever threshold for paying income taxes the Legislature chooses, so that the issue of a tie-in would be irrelevant. But they might be married and filing a joint return with a spouse and have income above the threshold. This introduces yet another complexity in designing the payroll tax.

\section{Low-Income Wage Earners}

For low-income persons, defined as those below the current $5 \%$ marginal tax bracket, their reduction in wages by the amount of the 
payroll tax would not be offset by the aggregate federal and Connecticut tax savings that would result, and they would be worse off. For example, before the imposition of a payroll tax, a single individual with Connecticut AGI of $\$ 40,000$ of Connecticut wages would pay a Connecticut income tax of $3.5 \%$, or $\$ 1,395$, and estimated federal taxes of $\$ 6,230$. This individual would take home $\$ 32,375$ ( $\$ 40,000-\$ 1,395-$ $\$ 6,230=\$ 32,375)$.

Assuming after the adoption of a 5\% payroll tax, her Connecticut wages would be reduced by $\$ 2,000$ to $\$ 38,000,{ }^{61}$ her State personal income tax would be eliminated, and her federal tax would be reduced to $\$ 5,837$. Her new take home would be $\$ 32,163(\$ 38,000-\$ 5,837)$, less than before the payroll tax was adopted. The reason why she is worse off is that her Connecticut income tax savings of $\$ 1,395$ and her federal tax savings of $\$ 393(\$ 6,230-\$ 5,837)$ combine for a total of only $\$ 1,788$ $(\$ 1,395+\$ 393)$, which is $\$ 212$ less than the $\$ 2,000$ reduction in wages. ${ }^{62}$ Unlike higher-income taxpayers whose take home increases, hers decreases.

A refundable tax credit would be one way of dealing with this situation. ${ }^{63}$ At the least, the credit would have to hold harmless every

${ }^{61}$ The actual reduction could be slightly less. See supra note 44 .

62 The numbers in the text come from the Project, supra note 42 . The reduction in wages overstates the amount needed to hold the employer harmless. The reduction needed to do so would be $\$ 1,905$. See supra note 44 , but that would not change the essential fact that this individual would be worse off after a payroll tax without any concomitant relief.

${ }^{63}$ Because of the opportunities for fraud, refundable credits are controversial. The refundable Earned Income Tax Credit, which has complicated rules, has a high error rate, which some attribute to fraud, but others attribute to unintentional errors reflecting the difficulty of dealing with the complexity. See, e.g., Robert Greenstein, et al., Reducing Overpayments in the Earned Income Tax Credit, Center on Budget and Policy Priorities (Jan. 31, 2019), 
individual below the current $5 \%$ bracket, so no one would be worse off after the adoption of the payroll tax, a reduction in wages, and a reduction in rates. The credit could be phased out at the point where the reduction in wages were equal to, or less than, the savings in state and federal taxes. ${ }^{64}$ Subject to revenue considerations, the credit could be even more generous than the hold-harmless amount and actually make everyone subject to the credit better off. ${ }^{65}$

The preceding discussion assumed that the employer could reduce an employee's wages. But if that did not occur, a refundable tax credit would be uncalled for. The State might wish to provide one for other reasons, but it would not be dictated by the rationale of the payroll tax. Without a tie-in, low-income employees would receive the benefit of a reduction in rates, even though their wages had not been reduced. No relief would be required. If a tie-in existed, however, employees would not receive any relief from the reduction in rates because they did not experience any reduction in their wages. They would remain in the same income tax position both before and after the adoption of the payroll tax.

https://www.cbpp.org/research/federal-tax/reducing-overpayments-in-theearned-income-tax-credit; Joel Barker, et al., Billions Lost Yearly to Earned Income Tax Credit: Errors or Fraud?, 14 J. Bus. Econ. Res. 145 (2016), Lynnley Browning, I.R.S. Targets Hartford on Tax Credit, N.Y. Times (Oct. 24, 2004), https://www.nytimes.com/2004/10/24/nyregion/irs-targets-hartford-on-taxcredit.html, What is the Earned Income Tax Credit?, Tax Policy Center, https://www.taxpolicycenter.org/briefing-book/what-earned-income-tax-credit. The DRS should be consulted on designing a refundable low-income credit. ${ }^{64}$ The Project estimates this would occur for a single person having Connecticut AGI of $\$ 50,000$. See supra note 42 at p. 3 .

65 In theory, this would increase the incentive for fraud. See id. The Consultant could simulate various combinations of rates and credits. 


\section{N. A New Rate Schedule: Version One}

Current Connecticut Personal Income Tax Rates range from 3\% to $6.99 \%$ on Connecticut AGI. The proposed payroll tax rate is $5 \%$. The goal is to substitute the proposed $5 \%$ payroll tax on employers paying Connecticut wages with a $5 \%$ reduction in the personal income tax. This would be accomplished by the employer shifting the payroll tax onto its employees by reducing their Connecticut wages by the cost of the payroll tax, and by the State reducing every existing bracket in the personal income tax by five points, which would eliminate the existing $5 \%$ and $3 \%$ brackets. $^{66}$

For example, someone now subject to the highest marginal tax rate of $6.99 \%$ (single filers with an AGI of $\$ 500,000$ ) would become subject to a $1.99 \%(6.99 \%-5 \%)$ rate. Each lower bracket until $5 \%$ would be similarly reduced by five points. The resulting brackets would be $0.5 \%$, $(5.5 \%$ $5 \%), 1 \%(6 \%-5 \%), 1.5 \%$ (6.5\%-5\%), 1.9\% (6.9\%-5\%), and 1.99\% (6.99$5 \%)$. The $5 \%$ and $3 \%$ brackets would be eliminated. Presumably, these lower rates would create favorable publicity for Connecticut.

Two difficulties arise with this approach. First, the assumption in lowering these brackets is that wages were actually reduced by the $5 \%$ payroll tax. That reduction was equivalent to paying a $5 \%$ income tax. In other words, the schedule implicitly assumes a tie-in. This is a critical point discussed above. ${ }^{67}$ If Connecticut wages were not reduced, the new rates would provide a windfall. Once again, the importance of a tie-in is demonstrated to implementing the rationale of a payroll tax.

\footnotetext{
${ }^{66}$ Alternatively, the brackets above $5 \%$ could be left unadjusted so the first one would start at $5.5 \%$.

${ }^{67}$ See Section III.B.
} 
Second, with no tie-in, a potential constitutional issue of discriminating against interstate commerce exists. Any tax reduction limited to only Connecticut wages would be suspect, and might have to be extended to all wages, including those for services performed out-of-state, even if the payroll tax did not cover those. ${ }^{68}$ Any approach that taxed wages for services performed outside the state at a higher rate than Connecticut wages would be constitutionally suspect.

If the revenue at stake between extending the new brackets to all wages and extending it to only Connecticut wages is not great, the more cautious approach is to let all wages benefit. Besides avoiding any administrative problems, the possible constitutional issue would be avoided. If, however, the revenue is substantial, the constitutional issue would justify a more thorough analysis.

If a tie-in existed, there would now be a reason for not extending the benefits of a tax reduction to all wages. The reason would be that if wages were not reduced, the wage earner would not be entitled to the benefits of a tax reduction. Presumably, there would be Connecticut wages that were not reduced, and these would also not benefit from the rate reduction. Taxpayers with out of state wages that were not reduced could not argue that their treatment was based on geography. The disparate treatment would not be based on geography, but rather on whether wages had been reduced. The fact that there would be Connecticut wages not benefiting from the rate reduction in addition to out-of-state wages should provide a defense to a constitutional attack.

${ }^{68}$ See supra note 21 and accompanying text. 
If the individual had non-wage income such as dividends, capital gains, interest, rents and the like, the policy underlying the payroll tax would not require these items should benefit from a rate reduction. ${ }^{69}$

One lesson to draw from the preceding is that three rate schedules might co-exist: one for wage income that was reduced, one for wage income that was not reduced, and one for non-wage income.

\section{O. A New Rate Schedule: Version Two}

Because of Connecticut's large per capita income, high-income individuals would save significant amounts of federal income tax and FICA taxes from a reduction in wages coupled with a State tax reduction. Even if there were no reduction in wages, they would still save from the lowered rates, assuming no tie-in.

The bill passed by the General Assembly seeks to share in this savings by increasing the brackets in Version One above by one point, starting with the current $6.5 \%$ bracket, which would otherwise have been reduced to $1.5 \%$ (6.5\%-5\%). Accordingly, the $1.5 \%$ bracket would now become $2.5 \%$, the $1.9 \%$ bracket (6.9\%-5\%) would become $2.9 \%$, and the $1.99 \%$ bracket (6.99\%-5\%) would become $2.99 \%$.

\footnotetext{
${ }^{69}$ The issue is similar to the discussion about who should receive the benefits of eliminating the $5 \%$ rate. See Section III.B.
} 
The proposed rate schedule would be as follows: ${ }^{70}$

\begin{tabular}{|c|c|c|c|c|}
\hline AGI Single Filer & AGI Joint Filers & $\begin{array}{c}\text { Existing Personal } \\
\text { Income Tax } \\
\text { Rate }\end{array}$ & Payroll Tax & $\begin{array}{c}\text { Proposed New } \\
\text { Income Tax } \\
\text { Rate with } \\
\text { Payroll Tax }\end{array}$ \\
\hline$\$ 0$ & $\$ 0$ & $3.00 \%$ & $5.00 \%$ & $0.00 \%$ \\
\hline$\$ 10,000$ & $\$ 20,000$ & $5.00 \%$ & $5.00 \%$ & $0.00 \%$ \\
\hline$\$ 50,000$ & $\$ 100,000$ & $5.50 \%$ & $5.00 \%$ & $0.50 \%$ \\
\hline$\$ 100,000$ & $\$ 200,000$ & $6.00 \%$ & $5.00 \%$ & $1.00 \%$ \\
\hline$\$ 200,000$ & $\$ 400,000$ & $6.50 \%$ & $5.00 \%$ & $2.50 \%$ \\
\hline$\$ 500,000$ & $\$ 500,000$ & $6.90 \%$ & $5.00 \%$ & $2.90 \%$ \\
\hline
\end{tabular}

This rate schedule is teed off of the $5 \%$ rate. The Commission would have to decide whether to carry over the existing exemptions in the current rate schedule to this new one, and how to allocate any exemption, if at all, between income from wages and income from nonwages. In addition, the Commission would have to decide how to apply the existing recapture rules. The Consultant should be able to calculate the revenue aspects of these decisions and how many residents at different income levels would owe how much income tax. ${ }^{71}$

\section{P. Commuters}

\section{Connecticut Residents Commuting to other States}

Suppose a Connecticut resident commutes to New York and earns all of her income there. Under existing law, she would pay New York State

\footnotetext{
${ }^{70}$ The rates are set forth in P.A. $19-117$, Sec. 385 , the statute creating the Commission.

${ }^{71}$ The Project estimates that $2 / 3$ of current Connecticut taxpayers would no longer owe any State income tax, supra note 42 at p.3.
} 
income tax and receive a credit for that tax against the Connecticut income tax. Because New York's rates are generally higher than Connecticut's, it is likely that she would pay no Connecticut income tax because the credit for the higher New York income taxes would offset the lower Connecticut income taxes. The commuter would bear the higher rate of New York income taxes. No double taxation would result. If Connecticut adopts a payroll tax, and assuming it would not apply to her non-Connecticut wages, ${ }^{72}$ she would be in essentially the same position as before. Even if Connecticut were to apply the payroll tax to her wages and the employer reduced her wages accordingly, she would still bear no Connecticut income tax because the credit for the New York income tax would fully offset her Connecticut income tax, which would be lower than before because of the reduction in her wages. She will still continue to be taxed at the higher New York rate.

Suppose the resident commutes to a state with a lower rate of income tax than Connecticut, e.g., New Hampshire, which does not tax wages. There would be no New Hampshire income tax to credit, and the resident would now bear the full amount of the Connecticut income tax whether her wages remained the same or were reduced. Conceptually, her situation would be the same after the adoption of a payroll tax as it was before.

\section{Resident of another State Commuting to Connecticut}

Suppose a New York resident commutes to Connecticut and earns all of her income here. New York would give the commuter a credit for the Connecticut personal income tax. Because the rate of the Connecticut income tax is generally less than that of New York, the commuter would pay the difference in rates to New York. The net effect is that the

${ }^{72}$ See supra note 22 and accompanying text. 
commuter from New York would pay tax to both Connecticut and New York, at a combined rate that would be no higher than the New York rate. No double taxation would result.

The commuter would be earning Connecticut wages, clearly subject to the payroll tax. Whether or not those wages were reduced by the cost of the payroll tax, and whether or not a tie-in existed, New York would presumably still credit the resulting Connecticut tax against her New York tax. Conceptually she is in the same situation both before and after the payroll tax in that her total rate of income tax will be set by New York.

\section{Grand Summary: From the Weeds to the Forest}

Getting into the weeds of the payroll proposal is essential to understand its strengths and weaknesses but can be distracting from seeing the forest. The best way to summarize the above examples and discussion is as follows.

Employers would have a new 5\% payroll tax imposed on the payment of their Connecticut wages, the cost of which is assumed would be passed onto employees through a $5 \%$ reduction in their Connecticut wages. In Version One, existing brackets in the personal income tax would be reduced by five points - whether eliminated only if wages were reduced is a critical policy question. A refundable credit would hold harmless low-income persons below the $5 \%$ rate and thus preserve the progressivity in the existing personal income tax. In Version Two, the three highest brackets would be increased by one point. 
But there is more, which goes to the heart of the proposal. Many employees would have a reduction in their federal income taxes, ${ }^{73}$ and a reduction in their FICA taxes, both attributable to their reduced wages. ${ }^{74}$ This savings, combined with the reduction in the State income tax, would be greater than the reduction in their wages. Their takehome pay would increase, despite the reduction in wages. And the higher the income, the greater these savings.

Employers who were able to reduce wages would benefit from the reduced FICA taxes on those lower wages. The reduction in wages and the reduction in FICA taxes would more than offset the amount of the payroll tax they would pay. Some would have additional savings from reducing contributions to retirement plans that are tied to wages; others might use part of their FICA savings to offset the future reduction in retirement benefits of their employees.

The new progressive income tax rate schedule for wages that has been proposed (Version Two) would share with the State some of the benefits accruing to higher-income individuals.

Using recently released individual income tax data by the DRS for calendar year 2018, the Project has estimated the following major effects, based on Version Two and on the assumption that wages would be reduced by the amount of the payroll tax. ${ }^{75}$ They do not consider the federal or Connecticut corporate income taxes. The Project's estimates follow:

\footnotetext{
${ }^{73}$ This reduction would be attributable to the reduced income tax on their now lower wages.

${ }^{74}$ Reduced FICA taxes and wages could reduce retirement benefits. See Section V.1.

${ }^{75}$ School and State Finance Project Financial Model dated Jan. 31, 2020.
} 
An annual increase in Connecticut taxes would be approximately $\$ 586$ million, attributable to revenue from the payroll tax less the revenue lost from the States income tax reductions. This net revenue increase would be offset by the cost of the low-income taxpayer credit.

Determining this cost requires access to taxpayer data that is not publicly available but could be determined by the Consultant.

Annual savings to Connecticut businesses would be approximately $\$ 814$ million. This amount represents the savings from a $5 \%$ reduction in wages, plus the savings from reduced FICA taxes, less the amount paid in payroll taxes.

Annual savings to individuals would be approximately $\$ 901$ million. These savings come from reduced federal income taxes, reduced FICA taxes, and reduced Connecticut personal income taxes, less reductions in wages.

The net loser is the federal government. It loses approximately $\$ 2.3$ billion annually, consisting of $\$ 1.5$ billion of reduced federal income taxes and $\$ 800$ million from reduced FICA taxes.

The Consultant would have access to DRS data, which would allow it to refine the above estimates.

\section{Will an Employer be able to Reduce Wages to Offset the Cost of the new Payroll Tax?}

The key to implementing the rationale of the payroll tax is an employer's ability to shift the tax to employees through a reduction in their wages. If wages were reduced by the cost of the payroll tax, employers would benefit by the reduced amount of the FICA taxes that they would pay on the lower wages (partially offset by an increase in 
their federal and State income taxes from having a smaller deduction for their FICA taxes).

Employees would also benefit. The tax savings, both federal and State, would offset, and in some cases considerably offset, the reduction in wages. But employees can be excused for suspecting something cannot be right about a proposition that seems so counter intuitive-being better off with lower wages. It will require careful explanation with easy to understand charts, graphics, and simulations. Because employers would save FICA taxes on the reduced wages, they would have a strong incentive to educate their employees that less is actually more. Employers would also have reduced contributions to retirement accounts, although some employers might choose to use part of their FICA savings to offset otherwise reduced pension benefits.

If, however, wages cannot be reduced, employers would bear the full cost of the payroll tax and continue to pay the full amount of the existing FICA taxes. How employees would fare would depend on whether a tie-in existed. If wages were not reduced, and if no tie-in existed, lower-income taxpayers would receive a windfall from the refundable low-income credit, the premise of which is that they have borne the burden of the payroll tax. Other taxpayers would also receive a windfall. They would receive the benefit of the States income tax reductions without any concomitant reduction in their wages. They would have the best of all worlds. Their take-home pay would increase because of their Connecticut income tax savings and they would suffer no reduction in their wages. 


\section{Existing contracts controlling wages and wage increases.}

In the short-term, union contracts govern and control employee wages. ${ }^{76}$ Unless renegotiated, these contracts would prevent employers from offsetting the cost of a payroll tax through an immediate wage reduction.

According to the Bureau of Labor Statistics, ${ }^{77} 16.7 \%$ of employees $(280,000)$ in Connecticut are union members and workers who report no union affiliation, but whose jobs are covered by a union or an employee association contract. Unions have traditionally exercised power in excess of what this number might suggest. Unless there were overwhelming support for a payroll tax among the rank and file, it is doubtful that these contracts could be renegotiated in the short-term. Alternatively, instead of an immediate reduction in negotiated wages, an employer might be able to recover the cost of a payroll tax by modifying future wage increases. Suppose in a pre-payroll tax world an employer planned on a $2 \%$ increase in wages going forward. ${ }^{78}$ This increase could be reduced in amount, in its timing, or both combined. There may be other benefits an employer was contemplating that would now be dropped from consideration.

\footnotetext{
${ }^{76}$ https://www.bls.gov/regions/new-england/newsrelease/unionmembership_massachusettsandconnecticut.htm.

77 The Bureau of Labor Statistics, https://www.bls.gov/regions/newengland/newsrelease/unionmembership_massachusettsandconnecticut.htm\#umtable1.f.1. ${ }^{78}$ See supra note 42 at pp. 5-6.
} 
There may be non-union, private sector contracts with employees that already guarantee annual increases. These would have to be renegotiated as well.

The longer the period between the adoption of a payroll tax and its effective date, the more time employers would have to implement various strategies for adjusting wages. Otherwise, an employer would bear the cost of the tax and be unable in the short-term to pass it forward to employees. In addition, the $5 \%$ rate could be phased in over a period of years, which is what New York has done.

\section{The Special Case of the State as an Employer}

The State wears three hats. It is an employer and like any non-profit employer, it pays FICA taxes, which it has an incentive to reduce. If the payroll tax were imposed on it, another hat would be that of a taxpayer. The third hat would be that of the recipient of the payroll tax revenues. The second and third hats worn together mean that the tax is a wash and imposes no actual cost on the State that it has to shift onto its employees. This distinguishes it from all other employers, non-profit or otherwise, which have actual costs that they have to worry about reducing. One way of their doing so is by reducing wages. The State is under no similar pressure to do so.

Suppose that the reduction in State income taxes is extended to all wage earners, whether their salaries are reduced or not; in other words, no tie-in exists. The State has no need to reduce employee wages by $5 \%$ because there is no cost imposed by the payroll tax that has to be shifted. Yet if the State does nothing, the effect would be that State employees would receive a raise equal to the personal income taxes they no longer have to pay. This result may present a political 
problem if other taxpayers view the payroll tax as a disguised raise for State employees.

With no tie-in, State employees would already be in the best tax position possible. They would have received an increase in their take home pay from the reduction in State income taxes, without any reduction in their wages. But without a reduction in their wages, the State will not receive the benefits of reducing its payroll, reducing its FICA taxes, (and perhaps making smaller contributions to pension plans). These savings would have otherwise helped pay for the loss in revenue from reducing the State income tax.

From the perspective of State employees, they would be in the same position as employees of other employers that would be unable to reduce the wages of their employees and would have to absorb the payroll tax. Without a tie-in, those employees would also get the benefit of the reduction in State income taxes without any reduction in wages. Unlike all other employers, however, the State cannot convince its employees of the need to pass through the "cost" of the payroll tax because there would be no actual cost.

The dilemma is whether State employees should receive a windfall like other employees of employers who cannot reduce wages (assuming no tie-in), or whether the State should make some kind of adjustment to recapture some or all of the benefits of the reduction in State income taxes, in other words, some kind of ad hoc tie-in. No doubt strong opposition to any recapture can be expected from employees and their unions.

The real defect in this situation is that the benefit generated by reducing the State income tax is not tied to a reduction in wages. If there were a tie-in, State employees would be better off if the payroll 
tax were paid by the State and their wages reduced, which could reduce their opposition.

Assuming no tie-in, three major options exist. One, impose the payroll tax on the State, and attempt to reduce its employee wages accordingly, generating savings from the reduction in wages and in its FICA taxes. Without a tie-in, however, why would employees and their unions accept this? The employees are already in the optimal tax position: a reduction in State income taxes with no offsetting wage reduction.

Two, do not impose the payroll tax on the State and let its employees benefit from the lack of a tie-in and the reduction in the State income tax. The difficulty would be the loss in revenue and the possible adverse public perception that State employees have been given a raise.

Three, do not impose the payroll tax on the State and recapture some or all of the benefits from the rate reduction. In a sense, this would be tantamount to a full or partial tie-in and would presumably face strong union resistance.

On the other hand, if a tie-in existed, employees would have two choices. First, they could support a payroll tax imposed on the State and accept a reduction in wages, and in return receive the benefits of the reduction in State income taxes, lowered FICA taxes, and lowered federal income taxes, leading to an increase in their take home pay. Their retirement benefits, however, might be reduced because of lower FICA taxes or reduced State contributions to their pensions, but the State could use part of its FICA savings to offset the reduced retirement benefits.

Second, State employees could vote for the status quo: rejecting any benefit from reducing State income taxes and rejecting any reduction in 
salary. The latter, of course, would leave them in the same position that they are in today.

New York State did not opt into its elective payroll tax, but it gave no reasons for its decision.

\section{Employee Perceptions}

One of the biggest potential obstacles to support for a payroll tax, even with a tie-in, would be employee resistance. Employees are simply used to negotiating for pay increases, not accepting reductions. A tie-in would change that traditional thinking. The reduction in wages would be offset by the reduction in State income taxes, and when the federal income and FICA savings are taken into account, most employees would be better off, and their take-home pay would increase.

Employees need to understand the underlying arithmetic and why they would come out ahead in take-home pay despite their wages being reduced-why less is more. Detailed spread sheets produced by the Consultant, based on information available from the DRS, and a fullfledged public information campaign would be required as part of that educational process.

Another potential obstacle is that employees' Social Security benefits are tied to their earnings history. Lower wages can translate into lower benefits. Americans are notoriously poor savers, ${ }^{79}$ and many retire with

79 "About half of households age 55 and older have no retirement savings (such as in a 401(k) plan or an IRA) ... Social Security provides most of the income for about half of households age 65 or older." U.S. Gov't Accountability Office, GAO15-419, Retirement Security: Most Households Approaching Retirement Have Low Savings, p.2 (2015); “[A]ccording to a July 2019 'GoBankingRates.com' survey, $42 \%$ of Americans risk reaching retirement age, without having sufficient savings to see them through the rest of their lives. The same survey found that nearly half of Americans polled had less than $\$ 10,000$ set aside for their later years. Rebecca 
little other than Social Security. ${ }^{80}$ Employer pensions and contributions to deferred savings vehicles are also similarly tied to wages, which means that reduced wages today would translate into lower benefits tomorrow.

To be sure, if the increased take-home pay were invested over a sufficiently long period of time, an employee might come out ahead upon retirement, but this calls for discipline, a degree of financial sophistication, and perhaps serendipity. But financial planners can be expected to participate in this potential new market by offering specially tailored savings options. Also, simulations by the Consultant could facilitate an employee's decision making.

Because of the FICA taxes they would save, employers would have strong incentives to help employees evaluate their options and encourage them to support a reduction in wages. And employers could

Lake, 60 Years Old and No Retirement Savings, The Balance (Oct. 23, 2019), https://www.thebalance.com/retiring-without-savings-at-60-years-old-4161009. "As of 2013, the median retirement account balance among all households 55 to 64 was only $\$ 14,500$. Even after excluding all households that had saved nothing, the median account balance of near-retirement households was still only $\$ 104,000$. If a household uses all of this money to purchase an annuity from a life insurance company that will pay a guaranteed monthly income for the rest of the household's life, this income will provide only approximately $\$ 5,000$ per year in retirement-nowhere near what the household is likely to need." Keith Miller, et al., The Reality of the Retirement Crisis, Center for American Progress (Jan. 26, 2015),

https://www.americanprogress.org/issues/economy/reports/2015/01/26/105394 /the-reality-of-the-retirement-crisis/

80. "Social Security is the most important source of income for seniors," Monique Morrissey, The State of American Retirement: How 401(k)s have failed most American workers, Economic Policy Institute (Mar. 3, 2016), Figure 22, https://www.epi.org/publication/retirement-in-america/. 
use some of their FICA savings to offset the adverse impact on their employees' retirement benefits.

Even if take-home pay increases, other situations might exist in which reduced wages could have collateral effects. These could include applying for a loan or credit, negotiating alimony or child support, or negotiating debt repayments, and the like. Some of these situations may already focus on take-home pay; others may focus on gross salary. In some of these situations reduced wages might be favored by the employee; in other situations, increased take-home pay might be favored. Over time, the relevant decision-makers may come to focus on take-home pay rather than wages.

Another collateral effect is that existing or potential employees of a multistate corporation might have difficulty understanding why two similarly classified jobs carry a different salary depending on whether they are in Connecticut or a neighboring state. Someone being recruited might not understand why the starting salary in a neighboring state is higher than the identical job in Connecticut. Again, this difference can be explained if given the chance. But a potential employee perusing the internet might dismiss the posted Connecticut job opening long before the difference can be unbundled.

Large HR departments should be used to recruiting potential employees with spread sheets showing things like cost of living, taxes, crime, quality of schools, recreational activities, and everything else that may be of interest to a possible hire. The payroll tax and its effect on take-home pay would become just another line item in the presentation.

Many corporations, and certainly the larger ones, use a well-known third party to manage their payroll function. That party can easily 
provide spread sheets on the take-home pay on various salary levels in various states.

\section{Employer Perceptions}

Despite the name "payroll tax," employers that can reduce wages to fully offset the cost of the tax could realize significant reductions in FICA taxes. For them, the so-called payroll tax is anything but a tax. Savings might also accrue from reduced contributions to deferred compensation arrangements, health plans, and the like, because these are usually tied to wages. Some employers, however, may hold employees harmless from these reduced contributions by using some of their FICA savings to maintain pre-payroll tax levels of contributions or by adjusting retirement benefits.

\section{It is Uncertain Whether the Payroll Tax will Trigger the Retaliatory Tax Paid by Connecticut Insurers to other States in which they are Doing Business ${ }^{81}$}

The retaliatory tax is unique to the insurance industry. The primary goal of the retaliatory tax is to promote uniform and moderate rates of taxation of the insurance industry throughout the country. The retaliatory tax seeks to achieve a level playing field for out-of-state and domestic insurance companies. The retaliatory tax was based on a model statute promulgated by the insurance industry. ${ }^{82}$

\footnotetext{
${ }^{81}$ In the interests of disclosure, I represented American Fire and Casualty in its successful challenge to an aspect of New Jersey's retaliatory statute. American Fire and Cas. Co. v. New Jersey Div. of Taxation, 189 N.J. 65 (2006).

82 Western \& Southern Life Ins. Co. v. State Bd. Of Equalization of California, 451 U.S. $648,669$.
} 
To illustrate the working of the retaliatory tax in a straightforward simple situation, assume that most states have a $2 \%$ premium tax, but State $A$ has a $3 \%$ premium tax. Suppose an insurance company incorporated in State A does business in State B, which has a $2 \%$ premium tax. Because the premium tax in State $A$ is one point higher than the premium tax in State B, the State A insurance company will be subject to a retaliatory tax of one point. That tax will be in addition to State B's premium tax of $2 \%$, bringing the total premium tax on the State $A$ insurance company to $3 \%$, rather than $2 \%$.

The expectation, well supported by experience, is that State A insurance companies will lobby their home state to lower their premium tax rates and thus reduce or eliminate the retaliatory taxes imposed by other states. When State A lowers its rate of premium tax, State A insurance companies will have their retaliatory taxes reduced elsewhere or perhaps eliminated, making them more competitive. And insurance companies from other states with say 3\% premium taxes doing business in State A might now become subject for the first time to A's retaliatory tax, causing them to lobby their home states to reduce their rates. The retaliatory tax is working as the industry and state legislatures intended when a rate cut in one state is matched with rate cuts around the country. This goal has been generally achieved.

The retaliatory tax is blatantly discriminatory. Typically, there are three provisions of the U.S. Constitution under which a discriminatory provision would be challenged. The first is the Commerce Clause, which is inapplicable to the business of insurance because of the McCarran Ferguson Act. ${ }^{83}$ The second is the Privileges and Immunities Clause of Art. IV, $\S 2$, of the U.S. Constitution, which is inapplicable to corporations and thus has no application to retaliatory taxes. The final

8315 U.S.C.S. § 1011 et seq. 
provision is the Equal Protection Clause, which requires only that the discrimination between foreign and domestic corporations bears a rational basis.

In a case challenging California's retaliatory tax, the Court broke the equal protection analysis into two parts: (1) Does the challenged legislation have a legitimate purpose, and (2) Was it reasonable for the lawmakers to believe that use of the challenged classification would promote that purpose ${ }^{84}$

The Court answered these questions in the affirmative and upheld the California retaliatory tax. "The legislative purpose of California's retaliatory tax is not difficult to discern, for such taxes have been a common feature of insurance taxation for over a century. Although variously expressed, the principal purpose of retaliatory tax laws is to promote the interstate business of domestic insurers by deterring other States from enacting discriminatory or excessive taxes." 85

The critical question is whether other states would interpret their retaliatory taxes as covering payroll taxes? Resolving this issue is critical to the industry. No other state has a mandatory payroll tax. ${ }^{86}$ If the Connecticut payroll tax is retaliated against, the cost of writing insurance in another state could increase, perhaps significantly.

Connecticut insurance companies would not be competing on a level playing field in any state that retaliated for the payroll tax.

${ }^{84}$ Western \& Southern, 451 U.S. at 668.

$85 \mathrm{Id}$.

${ }^{86}$ New York has an elective payroll tax. See supra note 5 and accompanying text. 
To illustrate the issue, a sampling of some retaliatory statutes follows. ${ }^{87}$ They have been paraphrased to be more readable and to cover the situation of a Connecticut insurer doing business in another state.

- Wisconsin: If Connecticut requires Wisconsin domestics to pay taxes greater in the aggregate than Wisconsin charges Connecticut domestics, retaliation occurs. Taxes are defined as general purpose revenue taxes. ${ }^{88}$

- New Jersey: Taxes, fees, penalties, licenses, deposit requirement or other obligations imposed by Connecticut upon New Jersey insurers which are in excess of such items imposed by New Jersey upon New Jersey insurers will result in retaliatory taxes. ${ }^{89}$

- New York: If insurers domiciled in New York are required by Connecticut to pay taxes, fines, penalties, fees, or any other sum greater than those required of Connecticut insurers by New York, retaliation will occur. ${ }^{90}$

- Arizona: If Connecticut premium or income or other taxes, or any fees, fines, penalties, licenses, deposit requirements or other material obligations are, in the aggregate, in excess of those Arizona applies to Connecticut insurers, a retaliatory amount is due. [Special carve outs apply to personal income taxes, property taxes, and special assessments. $]^{91}$

- California: If any taxes, licenses, and fees, in the aggregate imposed by Connecticut on California insurers, are in excess of the

\footnotetext{
${ }^{87}$ Research into the actual forms used by other states to calculate and collect the retaliatory tax was hampered because approximately $20 \%$ of the states require only on-line filing, and an account is necessary to access the retaliatory tax forms. ${ }^{88}$ WI. Stat. Sec. 76.66.

${ }^{89}$ N.J. Stat. 17B:23-5 (life insurers).

${ }^{90}$ N.Y. Ins. Law Section 1112.

${ }^{91}$ Ariz. Stat. Sec. 20-230.
} 
amounts charged by California on Connecticut insurers a retaliatory tax shall be imposed [Special carve outs apply to property taxes. $]^{92}$

- Florida: If Connecticut charges taxes, license, and fees in the aggregate to Florida insurers that exceed those that Florida imposes on Connecticut insurers retaliation will occur. [Special carve outs apply to personal income taxes, sales or use taxes, and property taxes.] ${ }^{93}$

- Pennsylvania: If Connecticut imposes taxes, fines, penalties, licenses, fees, etc. on Pennsylvania insurers that are higher in the aggregate than Pennsylvania would impose on Connecticut insurers retaliation will occur. ${ }^{94}$

- Maine: If Connecticut imposes any taxes, licenses and other fees, in the aggregate, and any fines, penalties, deposit requirements or other material requirements, obligations, prohibitions or restrictions on Maine insurers that exceed what Maine would impose on Connecticut insurers the same taxes, licenses and

${ }^{92}$ Calif. Const. Art. XIII, Sec. 28(f)(3), I.C. Sec. 685. In Western \& Southern, supra note 84 , U.S. Supreme Court described retaliation as existing "when the insurer's State of incorporation imposes higher taxes on California insurers doing business in that State than California would otherwise impose on that State's insurers doing business in California. In computing the retaliatory tax owed by a given outof-state insurer, California subtracts the California taxes otherwise due from the total taxes that would be imposed on a hypothetical similar California company doing business in the out-of-state insurer's State of incorporation. If the other State's taxes on the hypothetical California insurer would be greater than California's taxes on the other State's insurer, a retaliatory tax in the amount of the difference is imposed. If the other State's taxes on the hypothetical California insurer would be less than or equal to California's taxes, however, California exacts no retaliatory tax from the other State's insurer." 451 U.S. at 650. ${ }^{93} \mathrm{FL}$. Sec. 624.5091, Rule 12B-8.016.

${ }^{94}$ PA. Stat. 40-1-213; 40 P.S. Sec. 50. 
other fees, in the aggregate, or fines, penalties or deposit requirements or other material requirements, obligations, prohibitions or restrictions of whatever kind shall be imposed upon Connecticut insurers. [Special carve outs apply to personal income taxes, and property taxes. $]^{95}$

Although these statutes are not identical, they follow the same general pattern. They ask whether Connecticut's taxes on a foreign insurance company would exceed the foreign State's taxes on a Connecticut insurance company doing business in that other State. If so, retaliation could be triggered. If Connecticut would impose a $5 \%$ payroll tax on out-of-state insurance companies doing business in the State, and the other State would not have a similar payroll tax, retaliation could occur.

But apparently in some cases the instructions or forms for calculating the retaliatory tax cut back on the otherwise broad sweep of a state's retaliatory statute. In other words, in some situations the statutes have more bark than bite.

For example, the instructions for the Arizona tax provide that insurers from Connecticut are only required to use insurance tax rates, assessments for health insurance pools, and application and admission fees in calculating the retaliatory tax. ${ }^{96}$ The Arizona statute above, by contrast, refers more broadly to "taxes."

The California form for calculating the retaliatory tax uses only the tax rate on gross premiums plus any fire department tax, fire marshal tax, annual statement fee, certificate of authority fee, certification fee,

${ }^{95}$ Me. Stat. tit. 24-A, § 428.

${ }^{96}$ AZ Form E-RT and Arizona Retaliation Guide. 
agent license fee, ocean marine tax, franchise tax, and municipal tax. ${ }^{97}$ The statute is broader.

Despite the broad Maine statute above, the form for calculating the retaliatory tax is limited to only the premium tax on different lines of insurance..$^{98}$

New Mexico provides an even more extreme example. Since 2009, the Commissioner of Insurance has exercised his discretion not to enforce the retaliatory tax. ${ }^{99}$

The forms will sometimes reflect the difficulty of taking certain taxes into account in calculating the retaliatory tax even if the statute would allow it. Property taxes are a nice illustration. In recognition of the difficulty of including property taxes in the retaliatory calculation some statutes carve them out from inclusion. But even where no carve out occurs, as a matter of custom and tradition property taxes are often excluded anyway.

Statutes, however, prevail over forms, which represent an executive agency's views and not those of a legislature. A decision by a current administrator implemented through a form, which ignores the statute, can be changed by his or her successor. New Mexico 's administrative position of ignoring the State statute has already been criticized in a special audit conducted by the New Mexico Office of the Superintendent of Insurance. ${ }^{100}$

\footnotetext{
${ }^{97}$ CA Form CDI FS-002.

${ }^{98}$ ME Form INS-4.

99 New Mexico Bulletin 2009-008.

100 New Mexico Office of the Superintendent of Insurance, Special Audit of New Mexico Premium Tax Filings for the Period January 1, 2003 Through December 31, 2016, p. 25.
} 
The majority of states have retaliatory statutes that are not limited or narrowed by their forms or instructions. That leaves open the question of how a retaliatory statute referring to "taxes" would be interpreted in response to a payroll tax.

Connecticut has a retaliatory tax similar to these other states. The Connecticut retaliatory tax compares "premium or income or other taxes or any fees, fines, penalties, licenses, deposit requirements or other obligations, prohibitions or restrictions" and retaliates if a Connecticut insurer pays in another state more than an insurer from that state would pay in Connecticut. A carve out is provided for property taxes and personal income taxes. ${ }^{101}$

The question can be easily asked how Connecticut would apply its retaliatory tax if the State had not enacted a payroll tax, but another state had. Connecticut's retaliatory tax is administered by the DRS and not by the insurance department, unlike some other states. The Commissioner of Taxation is an ex officio member of the Commission. The question can be easily asked of the Commissioner, but the answer will not necessarily have much probative value. Other states will not be bound by what Connecticut would or would not do. Because a payroll tax is unprecedented, the issue is one of first impression. Unfortunately, the Commission needs to resolve this issue laboring under incomplete information on retaliation.

Three approaches are conceivable. The least feasible of the three is for the State to work through the National Association of Insurance Commissioners (NAIC) to determine whether there would be retaliation. The NAIC is the U.S. standard-setting and regulatory support organization created and governed by the chief insurance regulators

${ }^{101}$ Conn. Gen. Stat. $\S 12-211$. The retaliatory tax form does not limit the statute. 
from the 50 states, the District of Columbia and five U.S. territories. Through the NAIC, state insurance regulators establish standards and best practices. The NAIC, however, cannot legislate on behalf of a state; it has only a hortatory role. It also meets only three times a year. There would be no quick decision on the retaliation issue.

The second approach would be for Connecticut to exempt all insurance companies, both domestic and foreign, from the payroll tax. This would avoid the retaliatory tax. Presumably, employee wages would not be reduced. If there were a tie-in, the employees would get no advantage from the elimination of the $5 \%$ bracket, and no reduction in their federal taxes. Similarly, the companies would get no reduction in the FICA taxes they pay, or any reduction in payments to savings vehicles or bonuses that are based on wages. If employees realized that they would be better off if their employers paid the payroll tax and reduced wages, they might lobby against an exemption for the companies.

If there were no tie-in so that employees would receive the benefit of the elimination of the $5 \%$ rate, they would have no reason to oppose an exemption for the industry. They would be in an optimal tax position, receiving the benefits of the $5 \%$ bracket being eliminated with no reduction in their wages.

The third approach would be for the State to impose the payroll tax on only domestic Connecticut insurers. No retaliation would result. If there were a tie-in, knowledgeable employees would support a reduction in their wages because that would reduce their federal income taxes and FICA taxes, and Connecticut income taxes from the elimination of the $5 \%$ bracket. The companies would have the benefit of a reduction in the FICA taxes they pay, and a reduction in payments to savings vehicles or bonuses that are based on wages. With no tie-in, employees 
would be expected to oppose any reduction in wages because they would already be in an optimal tax position.

To be sure, while there would be no retaliation by other states under this third approach, domestic insurers would pay a payroll tax that their out-of-state competitors doing business in Connecticut would not pay. That would increase their cost of doing business. If they could pass the payroll tax onto their employees through a reduction in wages, they would reduce the FICA taxes they would otherwise pay. If they did reduce wages, their HR departments would have the same challenge that other employers would have in competing for out-of-state talent, convincing potential recruits that they will be better off with lower salaries but higher take-home pay. ${ }^{102}$

After taking soundings from many connected with the industry, former regulators, and tax specialists, I conclude that it is uncertain whether the payroll tax will trigger retaliation as a practical matter. Certainly, the retaliatory statues have broad enough language to cover a payroll tax, but the question is whether as a practical matter they will be interpreted to do so. More investigation is called for before this uncertainty can be evaluated.

One final note. If the payroll tax were elective, companies for whom the likelihood of retaliation would outweigh any savings in FICA taxes would presumably not opt in. The problem of retaliation would be eliminated. The question that would then arise is whether their employees would get the benefits of the $5 \%$ rate being eliminated.

102 See Section V.3. 


\section{A Payroll Tax Cannot be Imposed on the Federal Government Without its Permission}

The federal government and its instrumentalities are immune from state taxation. This hoary doctrine has its origins in the 1819 case of McCulloch v. Maryland. ${ }^{103}$

That case involved a Maryland tax imposed on the Bank of the United States, incorporated by an Act of Congress. No similar tax was imposed on Maryland banks.

Chief Justice John Marshall concluded that the Maryland tax was imposed on the operations of the Bank. Consequently, it was a "tax on the operation of an instrument employed by the Government of the Union to carry its powers into execution." 104 In hyperbolic dictum, the Court warned that the "power to tax involves the power to destroy."105 The Maryland tax was discriminatory because it applied only to the federal bank and not to state banks. The case suggests that a nondiscriminatory tax might have been upheld. The opinion "does not extend to ... a tax imposed on the interest which the citizens of Maryland may hold in [the Bank], in common with other property of the same description throughout the State." ${ }^{106}$

Unfortunately, McCulloch has not been limited to only discriminatory taxes. Today, McCulloch is interpreted to prohibit even nondiscriminatory state taxes on the federal government or its instrumentalities.

103 McCulloch v. Maryland, 17 U.S. 316 (1819).

$104 \mathrm{Id}$. at 436-37.

105 Id. at 431.

106 Id. at 436. 
The modern statement of the rule is set forth in United States v. New Mexico:107 "a State may not, consistent with the Supremacy Clause, U.S. Const., Art. VI, cl. 2, lay a tax 'directly upon the United States.' ${ }^{108}$ While '[one] could, and perhaps should, read M'Culloch ... simply for the principle that the Constitution prohibits a State from taxing discriminatorily a federally established instrumentality, ${ }^{109}$ the Court has never questioned the propriety of absolute federal immunity from state taxation. And after 160 years, the doctrine has gathered 'a momentum of authority that reflects, if not a detailed exposition of considerations of policy demanded by our federal system, certainly a deep instinct that there are such considerations .... '110" Id. at 733-34. Indirect taxes on the federal government, however, are constitutional. ${ }^{111}$ The Court drew a line between taxes that fell within the general application of nondiscriminatory laws, such as a tax on a government vendor, and a "direct burden ... upon the governmental instrumentality." 112 The Court stated that it was irrelevant whether the

107 United States v. New Mexico, 455 U.S. 720 (1982).

108 Mayo v. United States, 319 U.S. 441, 447 (1943).

${ }^{109}$ First Agricultural Bank v. State Tax Comm'n, 392 U.S. 339, 350 (1968) (dissenting opinion).

${ }^{110}$ City of Detroit v. Murray Corp., 355 U.S. 489, 503-504 (1958) (opinion of Frankfurter, J.).

${ }^{111}$ See, e.g., James v. Dravo Contracting Co., 302 U.S. 134 (1937), (holding that a gross receipts tax on a government contractor is constitutional even if the tax "may increase the cost to the government ..."). Id. at 160.

112 Id. at 150. See also Graves v. New York ex rel. O'Keefe, 306 U.S. 466 (1939)(upholding a New York income tax on an employee of the Federal Home Owner's Loan Association). 
state income tax increased the cost of labor to the federal government. ${ }^{113}$

The Court's position is inconsistent with its willingness in other contexts to substitute economic pragmatism for formalism. ${ }^{114}$ It is hard to understand why certain nondiscriminatory taxes imposed on the federal government should not be acceptable, such as a property tax or a payroll tax. Nonetheless, a challenge to the Court's doctrine that a tax imposed directly on the federal government is unconstitutional would be upheld by the lower courts and would require the U.S. Supreme Court to intervene. It is an avenue not worth pursuing.

Although a payroll tax imposed on the federal government would be unconstitutional notwithstanding that it would be nondiscriminatory, the federal government would be free to waive its immunity and agree to opt into the payroll tax regime. If it were to opt in and reduce wages, the government would receive less federal income taxes and FICA taxes, but would save from the reduction in wages and come out ahead. However, because of civil service constraints and unions, wages are unlikely to be reduced. ${ }^{115}$ This would be especially true if there were no tie-in so that federal employees would already be in an optimal tax situation by receiving the benefits inuring from the elimination of the $5 \%$ bracket with no reduction in wages. From this perspective, federal employees would be in the same situation as

${ }^{113}$ See also the companion cases of Alabama v. King \& Boozer, 314 U.S. 1 (1941); Curry v. United States, 314 U.S. 14 (1941), upholding sales and use taxes on government vendors that passed these taxes forward to the federal government. ${ }^{114}$ Complete Auto Transit v. Brady, 430 U.S. 274 (1977).

115 The Project estimates that federal employees represent about $1.1 \%$ of all Connecticut employees. See supra note 42 at p. 11 . The Consultant could estimate the wages of this group. 
employees of a private-sector employer that paid the payroll tax but could not shift it onto employees through wage reductions.

If the federal government did not agree to a payroll tax and if there were a tie-in, its employees would not have the benefit of the elimination of the $5 \%$ bracket.

If there were no explicit tie-in, the State could consider other means of recapturing some or all of the benefits of the $5 \%$ bracket from federal employees. In effect, this would impose an ad hoc tie-in. The risk with an ad hoc tie-in is that federal employees could argue that they were unconstitutionally discriminated against. If revenue considerations justify it, the merits of this constitutional argument would need further analysis.

If a tie-in were adopted across the board, covering all employees, and the federal government refused to waive its immunity, the constitutional argument would not arise

\section{A Payroll Tax Cannot be Imposed on an Indian Tribe in its Capacity as an Employer Without its Permission}

States do not have the power to levy a tax directly on a tribe's activities on a reservation unless Congress or the tribe authorizes it. "[A]bsent cession of jurisdiction or other federal statutes permitting it . . . a state is without power to tax reservation lands and reservation Indians."116

116 Oklahoma Tax Commission v. Chickasaw Nation, 515 U.S. 450, 458 (1995) (quoting County of Yakima v. Confederated Tribes and Bands of Yakima Nation, 502 U.S. 251, 258 (1992) (citation omitted)). 
"In the special area of state taxation of Indian tribes ... the [Court] has adopted a per se rule" against state jurisdiction. ${ }^{117}$

Application of this per se or "categorical" rule depends on where the legal incidence of the state tax falls. ${ }^{118}$ Thus, " $\left.\mathrm{t}\right]$ he initial and frequently dispositive question in Indian tax cases ... is who bears the legal incidence of the tax." 119

According to the United States Supreme Court:

"If the legal incidence of an excise tax rests on a tribe ... inside Indian country, the tax cannot be enforced absent clear congressional authorization." ${ }^{\prime 20}$

The proposed payroll tax is levied on the employer. The legal incidence of the tax is on the employer. Unless a tribe or Congress authorizes the payroll tax, it cannot be imposed on a tribe in its capacity as employing persons, whether Indians or not, on a reservation.

Furthermore, in the gaming context, the Tribal-State Compact between the Mohegan Tribe and the State of Connecticut provides that "Prohibition on taxation by the State. Nothing in this Compact shall be deemed to authorize the State to impose any tax, fee, charge or assessment upon the Tribe or any Tribal gaming operation except for charges expressly authorized pursuant to section 11 of this Compact." Id. Section 17(f). See also Proposal of the State of Connecticut for a Tribal-State Compact Between the Mashantucket Pequot Tribe, Section $17(f)$.

117 California v. Cabazon Band of Mission Indians, 480 U.S. 202, 215 n. 17 (1987).

118 Oklahoma Tax Commission v. Chickasaw Nation, 515 U.S. at 458.

119 Id.

${ }^{120}$ Id. at 459. 
Like the federal government discussed above, a tribe can elect to waive its immunity and opt into the payroll tax regime.

If no payroll tax is imposed on the tribe, their employees should not have the benefit of the elimination of the $5 \%$ bracket. An ad hoc tie-in could be adopted to deprive them of these benefits, as was discussed in the case of federal employees. The question is whether that would result in an unconstitutional discrimination against the tribe or its Indian employees. If revenue considerations make it worthwhile, that question would need to be pursued in greater depth.

Just like in the case of the federal government, if a tie-in existed across the board, and a tribe refused to waive its immunity, the constitutional issue would not arise.

\section{Should the Payroll Tax be Mandatory or Elective?}

If the tax is mandatory, the question becomes how many employers can shift the tax onto employees through reduced wages. If employers could not reduce wages, then for them the payroll tax becomes a new cost of doing business. For a labor-intensive, low-profit business, the tax could be excessive. Would this add to the image of the State as having a bad business climate, notwithstanding that Connecticut employees would benefit from the reduction in the State personal income tax if there were no tie-in? The question for economists is what effect would a tax on Connecticut wages paid by an employer that could not shift the tax to its employees, accompanied by a reduction in the Connecticut personal income tax, have on the State's economy? As important as this question is, it may be essentially unknowable.

If the tax is mandatory and the employer can shift it to employees through reduced wages, then the payroll tax will be working as intended. The $5 \%$ payroll tax on Connecticut wages would then have 
the effect of substituting for a $5 \%$ tax on Connecticut wages. Both employers and employees would come out ahead.

The ability to shift the tax onto employees could well change over time as labor conditions change. Both employers and employees would need assurance that the State would not adversely change key elements of the payroll tax going forward. The history in Connecticut with increases in rates once a tax is adopted does not necessarily offer this assurance. Nor does the recent experience with the reduction in the credit in the pass-through entity tax.

If the tax is mandatory with some employers being able to reduce wages to shift the cost to employees, while others would be unable, the tax would be a hybrid: neither fish nor fowl.

The Commission confronts a classic example of decision making in the light of uncertainty. Little experience exists for predicting how an employer would react to a $5 \%$ payroll tax. There is a worrisome downside in being wrong, with the payroll tax then becoming a tax on employers rather than a win-win proposition for employers and employees, with the federal government being the loser. ${ }^{121}$

New York's payroll tax is a cautionary tale. It is elective annually and phased-in over three years. The low participation rate, $0.1 \%$ of employers, is not encouraging. No major employer is participating, including the State itself. The New York legislation is dissimilar from what is being proposed in Connecticut so it is unclear what weight should be given to that State's low participation rate. More needs to be learned about how New York rolled out its payroll tax and the public relations and public education that accompanied it.

${ }^{121}$ See supra note 75 and accompanying text. 
An elective payroll tax would avoid it becoming a tax borne by the employer. Presumably, only those employers making the election would be confident that they could shift the cost to their employees. If that proved to be unrealistic, they would not have to continue the election. Conversely, employers that initially thought they could not shift the tax but later decided they could do so going forward, would subsequently make the election.

Only employees of an employer making the election should qualify for the rate reduction in the personal income tax. In a sense, the election implicitly serves as a tie in. Employees of employers not making the election would have no claim on receiving a windfall by benefiting from the rate reduction in the States personal income tax. Presumably, employees should support, if not lobby, for an election by their employers as it would increase their take-home pay.

After sufficient experience was gained with the tax, the participation rate could be evaluated, the revenue consequences determined, and administrative and policy dilemmas identified. The Legislature could then decide whether to make it permanent or continue the election. Of course, in the short-term the anticipated revenue for the State would have to be scaled back if it were elective unless the major employers in Connecticut chose to participate.

\section{Conclusion}

Many issues that need to be resolved were raised in both the text and in footnotes. The first part of this Conclusion gathers those issues with advice in some cases on the next steps to take.

- The threshold question is how many employers will be able to shift the payroll tax onto their employees? One view is that most employers will be unable to shift the tax. In that case, it becomes 
a new $5 \%$ tax on employment, coupled with a reduction in State income tax rates. This shift in tax from employees to employers should be debated explicitly and not implemented in the guise of an ineffective payroll tax.

- The opposing view is that employers typically can reduce their costs of doing business. As evidence, economists note that wages have not increased as much as some thought they should have given the low rate of unemployment. Employers have reduced costs of health care by increasing co-pays on employee insurance plans and imposing other constraints on coverage. Those who subscribe to this view will have faith that the cost of the payroll tax will be passed onto employees.

- Should the State provide a tie-in, that is, should the benefits of reducing State income tax rates be extended only to employees whose employers were able to reduce wages? This approach would minimize the State's costs and provide a way of dealing with the knotty issues presented by State, federal, and tribal employees. But could a tie-in be administered? The DRS needs to be consulted on this issue.

- Should the benefits of a reduction in the State personal income tax extend to all wages, only Connecticut wages, or only Connecticut wages that were reduced to accommodate the payroll tax? The correct policy answer would seem to be to limit these benefits to only those wages that were reduced because the employer shifted the payroll tax to the employee. This tie-in might be difficult to enforce without some attestation and proof from the employer or employees. The DRS should be consulted on how to audit this issue. The tie-in solves many knotty problems and deserves a thorough vetting. 
- If a tie-in is not feasible, the next possible approach would be to grant the benefits from reducing the State income tax to only wages that were subject to the payroll tax, whether they were reduced or not. An employer paying Connecticut residents working outside the State would not have those wages taxed under the payroll tax. Yet if those residents cannot benefit from the reduction in State income taxes, the result could be that outof-state wages would be taxed at a higher rate than Connecticut wages in those instances where income tax rates outside of Connecticut are lower, such as New Hampshire. This raises a possible constitutional issue of discriminating against interstate commerce. If little revenue were lost from allowing all wages to benefit from the reduction in personal income taxes, that would be the cautious approach to take. If, however, the loss was significant, the constitutional issue would merit a deeper analysis. A tie-in would likely blunt this potential constitutional attack..

- Non-wage income such as dividends, capital gains, interest, rent and the like should not benefit from the reduction in tax rates. The existing rate schedule (or a new one) should be applied to non-wage income.

- The possibility of three tax schedules exists; one for non-wage income, one for wages that were reduced by the amount of the payroll tax, and one for wages that were not reduced. Each schedule introduces an element of complexity.

- In applying the existing rates on non-wage income, should the amount of an individual's wages be considered? In other words, should persons with high wages pay at a higher rate on their nonwage income than those with the same amount of non-wage income but having much lower wages? 
- The refundable low-income tax credit raises the possibility of fraudulent returns. DRS needs to determine this risk and how to minimize it.

- The possibility of retaliation by other states to Connecticut insurance companies in response to the payroll tax needs to be evaluated very carefully.

- What is the revenue at stake from not being able to tax the employees of the federal government and of the Indian tribes?

- There is nothing sacrosanct about the $5 \%$ rate of payroll tax despite it being identical to the rate of New York's elective payroll tax. Hundreds of rates and rate schedules are possible, as are combinations of exemptions and recapture rules. All of this needs to be simulated.

- Should the payroll tax should be elective or mandatory, and if elective should it be phased-in? An election helps sort out those employers that can reduce wages from all others. A phase-in allows the State to gain needed experience with the tax.

- If elective, should the employees of an employer opting out nonetheless receive the benefits of the reduction in rates? A tie-in would automatically answer this question by denying the benefits to employees of employers that opted out.

- The New York experience with its elective payroll tax needs to be thoroughly investigated. Why has there been such a low rate of participation? What can the Commission learn from the way New York rolled out that tax? What was the public outreach like? What kinds of public education and awareness took place? How 
probative is New York's experience? Not enough information is known about the New York experience at this time.

- Another aspect of the New York approach needs to be explored in depth. New York grants a credit to the employee for the payroll tax paid by the employer. It does not reduce any of the rates in its personal income tax. The advantages and disadvantages of this approach need to be compared with our proposed payroll tax.

- Hiring a consultant should be a priority to answer the above questions and those raised in PA 19-117, Sec. 385, establishing the Commission.

If the Legislature decides to move forward with the payroll tax, it needs to control the narrative and should consider using a different name for the tax. To start with, the name "payroll tax" is inaccurate and has the wrong optics for an approach that is intended to reduce the State and federal taxes on both employers and employees. If it works as intended, with employers passing the tax onto employees through reduced wages, it is not a tax at all, but a way of increasing the takehome pay of Connecticut employees by reducing their State and federal income tax and by reducing the FICA taxes paid by them and their employers.

Notably, New York adopted a fairly clumsy name for its payroll tax, "Employer Compensation Expense Program. This name is both ambiguous and not very informative, but if anything, it sounds positive. Employers are not being taxed; they are being compensated for some unspecified "expense."

Adopting a new tax is always challenging. As those of us who worked on the original Connecticut income tax can attest, unanticipated issues will 
always come up in the drafting. And that was true despite many other states having had long experience with an income tax upon which we could draw. In the case of a payroll tax, by contrast, Connecticut has only New York to look to, and its approach is different from what is being proposed here.

The drafting challenges are daunting, but the Legislature is lucky to have superb and experienced personnel. The executive branch also has a wonderful resource in the DRS and the OPM. In addition, Connecticut is fortunate to have a very talented group of tax lawyers in the private sector, who have always given unselfishly of their time. Finally, the School and State Finance Project has spent more time working on a payroll tax than any other group. A joint venture among all of these groups would be invaluable in the drafting of a bill. 


\section{Richard D. Pomp}

Richard D. Pomp is the Alva P. Loiselle Professor of Law at the University of Connecticut Law School. He is a summa cum laude graduate of the University of Michigan and a magna cum laude graduate of Harvard Law School. He has taught at Harvard, New York University, Columbia, University of Texas, and Boston College. In addition, he has been a Distinguished Professor in Residence, Chulalongkorn Law School, Bangkok, Thailand, and a Visiting Scholar at the University of Tokyo Law School and at Harvard Law School.

Professor Pomp has been admitted as an expert witness in more than 30 states and the federal district courts and has appeared in more than 120 cases. He serves as counsel and a litigation consultant to law firms, corporations, accounting firms, and state tax administrations. He has participated in various capacities in Supreme Court litigation.

Professor Pomp has also served as a consultant to cities, states, the Multistate Tax Commission, the Navajo Nation, the U.S. Congress, the U.S. Treasury, the Department of Justice, the IRS, the United Nations, the IMF, the World Bank, and numerous foreign countries, including the People's Republic of China, the Republic of China, Indonesia, the Gambia, Zambia, Mexico, the Philippines, Pakistan, India, and Vietnam. $\mathrm{He}$ is the former Director of the New York Tax Study Commission. Under his tenure, New York restructured its personal and corporate income taxes, and created an independent tax court.

Professor Pomp's casebook, State and Local Taxation, now in its 9th edition, has been used in more than 100 schools, state tax administrations, and major accounting firms for their internal training. Portions of the casebook have been translated into Chinese, Dutch, German, Japanese, Spanish, and Vietnamese. He is also the author of more than 130 articles, numerous chapters in books, and various books 
and monographs. His writings have appeared in The New York Times, The Wall Street Journal, and the Financial Times.

In addition to the local and regional media, Professor Pomp has been interviewed by CNN, NPR, Time Magazine, Bloomberg Radio, Sirius Radio, KCBS, WINA, The New York Times, The Wall Street Journal, The Washington Post, the Christian Science Monitor, the Los Angeles Times, the Minneapolis Star Tribune, the Sacramento Bee, The Baltimore Sun and The International Herald Tribune.

In 2007, he received the NYU Institute on State and Local Taxation Award for Outstanding Achievement in State and Local Taxation. In 2011, he was awarded the Bureau of National Affairs (BNA) Lifetime Achievement Award. He was the 2012 winner of the University of Connecticut's Faculty Excellence in Teaching - Graduate Level. Tax Analysts selected him as its 2013 State Tax Lawyer and Academic of the Year. In 2014, he received the Council on State Taxation's Excellence in State Taxation Award. The Connecticut Law Tribune selected him for a 2015 Professional Excellence Award. He recently won the Perry Zirkel '76 Distinguished Teaching Award. 


\section{RICHARD D. POMP}

Connecticut Law School

Tel: $\quad 860983-8341$

65 Elizabeth Street

Fax: $860570-5242$

Hartford, Connecticut 06105

richard.pomp@uconn.edu

\section{ACADEMIC APPOINTMENTS}

Alva P. Loiselle Professor of Law, University of Connecticut, School of Law, 1992present; Professor of Law, 1979-present; Associate Professor of Law, 1976-1979.

Visiting Professor, Harvard Law School, 1999-2000.

Visiting Professor, NYU Law School, Fall 1988.

Distinguished Professor in Residence, Chulalongkorn Law School, Bangkok, January 1988.

Visiting Scholar, University of Tokyo Law School, December 1987.

Visiting Professor, Boston College, Fall 1987.

Visiting Scholar, Harvard Law School, 1984-1985.

Visiting Professor, University of Texas, Spring 1981.

Instructor of Law, Boston College Law School, 1975-1976.

Director, International Tax Program, Harvard Law School, 1973-1976.

\section{Courses Taught}

Federal Income Taxation, Corporate Income Taxation, International Taxation, Tax Policy, State and Local Taxation, American Indian Taxation.

\section{EDUCATION}

Harvard Law School, Cambridge, Massachusetts

J.D. 1972 magna cum laude

University of Michigan, Ann Arbor, Michigan

B.S. 1967 summa cum laude 


\section{RECENT PRIZES AND AWARDS}

Perry Zirkel '76 Distinguished Teaching Award, 2017.

Recipient of a Fulbright Award, 2015.

Connecticut Law Tribune, 2015 Professional Excellence Award.

2014 Council on State Taxation (COST), Excellence in State Taxation Award.

2013 State Tax Person of the Year, Tax Analysts.

2012 University of Connecticut's Faculty Excellence in Teaching---Graduate Level.

Bureau of National Affairs (BNA), Distinguished Service in State and Local Tax Law (2011).

All Decade State Tax Team, State Tax Notes, 2010.

NYU Institute on State and Local Taxation, Outstanding Achievement in State and Local Taxation (2008).

\section{PROFESSIONAL ACTIVITIES}

Consultant, Connecticut Office of Policy and Management, 2019-present.

Consultant, Washington Commissioner of Insurance, 2019-present.

Consultant, Washington Attorney General, 2016-2018.

Consultant, City of Kansas City, Missouri, 2015-2016.

Hearing Officer, Multistate Tax Commission, 2013.

BNA Tax Advisory Board, 2011-present.

Member, California Commission on the $21^{\text {st }}$ Century Economy, 2009-2010.

Co-Reporter for the Revision of the Uniform Division of Income for Tax Purposes Act (UDITPA), 2008-2009.

Advisory Board, State Sales Tax Alert, 2008-2010.

Member, Connecticut Streamlined Sales Tax Commission, 2007-2008.

Advisory Board, Pew Charitable Foundation Tax Project, 2007-2008. 
General Editor, Lexis Connecticut Practice Insights, 2006-present.

Member, Connecticut Business Tax Credit and Tax Policy Review Committee, 2005.

Consultant, State of Delaware, 2002.

Consultant, South Carolina Department of Revenue, 2002-2003, 2005-2006.

Consultant, Treasurer, State of New Jersey, 2002-2003.

Consultant, City of San Francisco, 2001-2003.

CCH, State Tax Advisory Board, 2000-2011.

Advisory Board, Interstate Tax Report, 2000-2010.

BNA Tax Management State Tax Advisory Board, 2000-present.

Consultant, California Legislature, 2000.

Consultant, State of West Virginia, 2000.

Consultant, California Franchise Tax Board, 2000.

Consultant, Alaska Department of Revenue, 1999-2010.

Consultant, New York Department of Taxation and Finance, 1998-1999.

Consultant, Pew Charitable Foundation, 1998-2000.

Consultant, U.S. Department of the Treasury, 1997-2000.

Consultant, Tennessee Attorney General, 1998-1999, 2001-2003.

Consultant, Montana Department of Revenue, 1998-1999, 2004-2008, 2016.

Consultant, U.S. Department of Justice, 1997, 2001.

Advisory Board, Deloitte \& Touche Center for Multistate Taxation at University of Wisconsin, 1997-2014.

Consultant, Louisiana Department of Revenue, 1995-2000.

Consultant, Utah Attorney General, 1994-1995.

Property Revaluation Task Force, Connecticut Institute of Municipal Studies, 1993. 
Consultant, IMF, 1993, 1999.

Consultant, Multistate Tax Commission, 1993, 1996-2004, 2009-2010, 2014, 2016.

Consultant, Illinois Department of Revenue, 1993.

Consultant, North Dakota Department of Revenue, 1992-1993, 1999-2005.

Consultant, IRS, 1992-94.

Editorial Advisory Board, State Income Tax Alert, 1992-present.

Book Review Editor, State Tax Notes, 1992-1994.

Columnist, Natural Resources Tax Review, 1992-1993.

Member, Blue Ribbon Committee on Municipal Overburden for the City of Hartford, 1991.

Advisory Board, State Tax Notes, 1991-present.

Consultant, Texas Comptroller of Public Accounts, 1991, 2002-2004.

Advisory Board, Center for State and Local Taxation, 1990-present.

Short Review Editor, Tax Notes International, 1989-1994.

Member, Connecticut Task Force to Study and Evaluate State Tax Revenue and the Current Tax Base, 1989-1991.

Special Counsel, Connecticut Senate Majority Leader, 1989, 1991.

Consultant, Ministries of Justice and Finance, The Gambia, 1989 (HIID).

Member, Consulting Group on Tax Policy and its Impact on Land Use, Lincoln Institute of Land Policy, 1988-present.

Consultant, Ministry of Finance, Republic of Indonesia, 1988-1989 (HIID).

Instructor, NYU-IRS Continuing Legal Education Program, 1988, 1989, 1991.

Educational Leader, Soviet-American Legal Tour, 1987.

Consultant, Connecticut Conference of Municipalities, 1987, 1989, 1991. 
Consultant, Connecticut Attorney General, 1986, 2002-2004.

Director, New York State Tax Study Commission, 1982-1987.

Consultant, Citizens for Tax Justice, 1981.

Consultant, Appalachian Research and Defense Fund, 1981.

Referee, National Tax Journal, 1980-2005.

Consultant, World Bank, 1980.

Chairman of the Board, Institute on Taxation and Economic Policy, 1979-2016.

Consultant, People's Republic of China, 1979-1982, 1987.

Advisory Committee, Assessment and Valuation Legal Reporter, 1979-1993.

Consultant, City of Hartford, 1978-1980.

Consultant, Connecticut Department of Education, 1978-1979.

Consultant, Hartford Chamber of Commerce, 1978-1979.

Consultant, United Nations Conference on Trade and Development, 1977-1978.

Consultant, Navajo Nation, 1977-82.

Consultant, U.S. Office of Technology Assessment, 1977.

Consultant, Ministry of Finance, Mexico, 1977.

Consultant, Commissioner of Taxation, Republic of Zambia, 1976-1978.

Consultant, United Nations Development Program, 1975.

Editor, European Taxation, and Research Associate, International Bureau of Fiscal Documentation, the Netherlands, 1972-1973.

Commissioned Officer, U.S. Public Health Service, 1968-1970. 


\section{PUBLICATIONS}

\section{BOOKS, REPORTS, AND MONOGRAPHS}

Myth Vs. ReAlity: AirbnB \& ITS Voluntary TAX COLleCtion EFFORTS (2019).

STATE AND LOCAL TAXATION (NINTH EDITION, 2019) (EARLIER EDITIONS OMITTED).

2017 CCH GUIDEBOOK TO CONNECTICUT TAXES (ED.) (EARLIER EDITIONS OMITTED).

MOdERNIZING THE STATE CORPORATE INCOME TAX: MARKET-BASED APPORTIONMENT FOR CONTENT PROVIDERS (MOTION Pictures ASSOCIATION OF AMERICA (2015)).

RePORT OF THE HEARING OfFicer, MUltistate TAX COMPACt ARTicLe IV [UDITPA] PROPOSED AMENDMENTS (2014).

StATE TAXATION OF AMERICAN INDIANS, THE TRIBES AND THOSE DOING BUSINESS WITH THEM: SOVEREIGNTy, InDian COMMERCE Clause, TREATIES AND Statutes (BNA, 2014).

TAXING SMARTER AND FAIRER: PROPOSALS FOR INCREASED ACCOUNTABILITY AND TRANSPARENCY IN THE CONNECTICUT TAX STRUCTURE (2005).

TAX PrefERENCES For Extractive Industries: Oil \& Gas, CoAl, Nonfuel Minerals, TIMBER, AND FISHING (2000) (WITH M. MCINTYRE).

People's Republic of China: TAXation AND the Rule of LaW (1999) (with J. Li et al).

CORPORATE TAX POLICY AND THE Right to KNOW: IMPROVING STATE TAX Policymaking by ENHANCING Legislative AND Public ACCESS (1993).

THE REVERSE TRANSFER OF TECHNOLOgY: Legal AND ADMINISTRATIVE ASPECTS OF COMPENSATION, TAXation ANd RELATEd Policy MEAsures (1977) (with O. Oldman). 


\section{ARTICLES}

Myth v. Reality: Airbnb \& its Voluntary Tax Collection Efforts, 93 State Tax Notes 187 (2019).

Did South Dakota Make a Strategic Error in Drafting its Wayfair Statute?, 37 J. of State Tax. 29 (2019).

The Disclosure of Individual Tax Returns: A Historical Overview, 92 State Tax Notes 1120 (2019).

Remote Foreign Vendors: The Only Thing to Fear is Fear Itself, 37 J. State Tax. 31 (2019).

GILTI or Not Guilty, 91 State Tax Notes 950 (2019).

Wayfair: Its Implications and Missed Opportunities, 58 Wash U.J. \& Policy 1 (Symposium Issue) (2019).

Wayfair and the Myth of Substantial Nexus, 36 J. State Tax. 21 (2018).

Interring Substantial Nexus-A Missed Opportunity, 89 State Tax Notes 858 (2018).

Inroads, Narrowings, and Restrictions, 90 State Tax Notes 1029 (2018).

Looking Forward and Backward, 86 State Tax Notes 1150 (2017).

Revisiting Miller Brothers, Bellas Hess, and Quill, 65 Am. U. L. Rev. 1115 (Symposium Issue) (2016).

Los Principios y Metodos Estatales de la Tributacion Multi-Jurisdicccional, 8 Quaestiol Iuris 1125 (2015) (with Rodriguez).

The Apportionment of Income: Reflections on the Multistate Tax Commission's (MTC) Proposals to Revise the Uniform Division of Income for Tax Purposes Act (UDITPA), National Tax Association, 107 $7^{\text {th }}$ Annual Proceedings (2014).

Apportionment Formula: Economische Unie en de Verdeling Van Inkomen, 24 Forfaitair, 19 (2011) (with Vlassaker).

The Unfulfilled Promise of the Indian Commerce Clause and State Taxation, 63 Tax Lawyer 902 (2010).

Die Gemeiname Konsolidierte Körperschaftsteuer-Bemessungsgrundlage: (R) Evolution der Konzernbesteuerung?, Internationales Steurrecht (2008) (with Gersten). 
A Policy Analysis of Michigan's Mislabeled Gross Receipts Tax, 53 Wayne Law Review 1283 (2008) (symposium issue with McIntyre); excerpted as Michigan's New Apportioned Value Added Tax, 51 State Tax Notes 673 (2009).

La Tributacion Multiestatal de Sociedades en Estados Unidos, 122 Cronica Tributaria 137 (2007) (with Maya).

Sales Tax in the United States-Theory and Practice, 7 European Law Review 81 (2006) (with Gradzki).

Formulary Apportionment in the United States: The System and the Cases, 56 Japan Taxation 77 (2005) (with Sho Hiraki).

State Tax Reform: Proposals for Wisconsin, 88 Marquette Law Review 45 (2004) (invitational symposium issue).

Show Me the Point! A Response to 'Show Me the Money,' 31 State Tax Notes 1095 (2004).

The Collision Between Nonprofits and the Cities Over the Property Tax: Possible Solutions, in Property Tax Exemptions for Charities: Mapping the Battlefield (E. Brody ed. 2002).

The Constitutionality of Michigan's Capital Asset Deduction, New York University Institute on State and Local Taxation 2001 (with Van Tifflin et al).

Designing a Combined Reporting Regime for a State Corporate Income Tax: A Case Study of Louisiana, 61 Louisiana Law Review 699 (2001) (invitational symposium issue, 2001) (with McIntyre and Mines).

Ruminations on Reforming Aspects of Connecticut's Tax Structure, 41 State Tax Notes 647 (2006).

A Brief History of the Electric Utility Industry, in IMPACTS OF ELECTRIC UTILITY DEREGULATION ON PROPERTY TAXATION (2000).

The Future of the State Corporate Income Tax: Reflections (And Confessions) of a Tax Lawyer, in The FutURE OF STATE TAXATION (D. Brunori, ed. 1998); reprinted in 16 State Tax Notes 939 (1999).

Post-Marriage Income Splitting Through the Deduction for Alimony Payments: A Reply to Professor Schoettle on Lunding v. N.Y., 13 State Tax Notes 1631 (1997) (with M. McIntyre).

State Income Tax Treatment of Residents and Nonresidents Under the Privileges and Immunities Clause, 13 State Tax Notes 245 (1997) (with M. McIntyre). 
Adrift Without a Rudder - A Response to Seaman Miethke, 11 State Tax Notes 487 (1996) (with M. McIntyre).

State Taxation of Mail-Order Sales of Computers after Quill: An Evaluation of MTC Bulletin 95-1, 11 State Tax Notes 177 (1996) (with M. McIntyre).

Commerce Clause Restraints on State Taxation After Jefferson Lines, 51 Tax Law Rev. 47 (1995) (with W. Hellerstein and M. McIntyre).

The Political Economy of Tax Return Privacy--Revisited, 8 State Tax Notes 2389 (1995).

Issues in the Design of Formulary Apportionment in the Context of NAFTA, 49 Tax Law Rev. 795 (1995).

GATT, Barclays, and Double Taxation, 8 State Tax Notes 977 (1995) (with M. McIntyre); a revision of Double Trouble: Double Taxation Aspects of Formulary Apportionment in the International Context, Proceedings of the 86th Annual Conference, National Tax Association 236 (Stocker ed. 1994).

Openness and Accountability in State Tax Policymaking, Proceedings of the 86th National Tax Association 83 (Stocker ed. 1994).

Turning the Clock Back to the Future: The Disclosure of State Corporate Tax Information, 22 Capital Law Review 373 (1993) (Symposium Issue); reprinted in 6 State Tax Notes 603 (1994).

Rethinking State Tax Expenditure Budgets, in 5 J. of Public Budgeting and Financial Manag. 337 (1993), a revision of State Tax Expenditure Budgets--And Beyond, in THE UnFINISHED AgENDA FOR STATE TAX REFORM, 65 (S. Gold ed. 1988); excerpted in Proceedings of the 81st Annual Conference, National Tax Association--Tax Institute of America 33 (Stocker ed. 1989).

The Tax Treatment of Condemnations, in AMERICAN LAW OF REAL PROPERTY (1993); a revision of The Tax Treatment of Condemnations and Other Involuntary Conversions, in POWELl On REAL PROPERTY (1991).

Are the Standards for Tax Jurisdiction and Personal Jurisdiction Identical?, 54 Tax Notes 333 (1992); 2 State Tax Notes 86 (1992).

Determining the Boundaries of a Post Bellas Hess World, 44 Nat. Tax J. 237 (1991), reprinted in 1 State Tax Notes 397 (1991); excerpted in 1 Sales and Use Tax Alert 5 (1992).

A Normative Inquiry into the Base of a Retail Sales Tax, 43 Nat. Tax J. 427 (1990) (with Oldman), reprinted in 1 State Tax Notes 170 (1991). 
Taxation in China, in DoING BusINESS IN CHINA (W. Streng and A. Wilcox eds., 1990) (with T. Gelatt).

The Like Kind Exchange of Real Property, in AMERICAN LAW OF REAL Property (1991); a revision of Nontaxable Exchanges of Real Property, in POWELL ON REAL PROPERTY (1990).

The Experience of the Philippines in Taxing its Nonresident Citizens, in INCOME TAXATION AND INTERNATIONAL PERSONAL MoBILITY (J. Bhagwati ed. 1989); a revision of The Experience of the Philippines in Taxing Nonresident Citizens, 17 NYU J. Int'l Law and Politics 245 (1985).

Restructuring a State Income Tax in Response to the Tax Reform Act of 1986, 36 Tax Notes 1195 (1987); a revision of Simplicity and Complexity in the Context of a State Tax System, in Reforming State Tax Systems (S. Gold ed. 1986); reprinted in Proceedings of the 80th Annual Conference, National Tax Association--Tax Institute of America 28 (Stocker ed. 1987); IsSUES IN STATE TAXATION (California Tax Policy Conference, 1987).

Reforming a State Corporate Income Tax, 51 Alb. L. Rev. 383 (1987) (Symposium Issue).

State Corporate Income Taxes: The Illogical Deduction for Income Taxes Paid to Other States, 42 Tax Law Rev. 419 (1987); reprinted in Multistate Tax Commission Review (September 1987).

The Use and Misuse of Interstate Tax Comparisons, 5 J. of State Tax'n 97 (1986); reprinted in 33 Tax Notes 87 (1986).

An Evaluation of New York's Sales Tax Audit Program, 5 J. of State Tax'n 3 (1986) (with J. Barrese); reprinted in 8 Municipal Finance J. 151 (1987).

Fairness and Function in the New York Tax Appeals System: Proposals for Reform, 49 Alb. L. Rev. 352 (1985) (with R. Plattner and R. Kay).

The Role of State Tax Incentives in Attracting and Retaining Business, 29 Tax Notes 521 (1985); reprinted in Multistate Tax Commission Review (1985); Colorado Municipalities (March-April 1986); New York Economic Development Working Papers \#4 (Rockefeller Institute of Government, 1987); excerpted in 13 People and Taxes (Sept. 1985).

State Tax Reform New York Style, in Proceedings of the 77th Annual Conference, National Tax Association--Tax Institute of America 192 (Bowers ed. 1985); reprinted in S. GOLD, STATE TAX STUDY COMMISSION: AN OVERVIEW OF FOUR APPROACHES (NCSL, 1985). 
Tax Aspects of Doing Business with the People's Republic of China, 22 Colum. J. Transnat'l L. 421 (1984) (with T. Gelatt); reprinted in CHINA'S LEGAL DEVELOPMENT (J. Oldham ed. 1986); a substantial revision of China's Tax System: An Overview and Transactional Analysis in FOREIGN TRADE, InVESTMENT AND THE LAW IN THE PEOPLE'S REPUBLIC OF CHINA 36 (M. Moser ed. 1 st edition 1984), revised and reprinted in $2 \mathrm{~d}$ ed. 1987 at 42; revised and reprinted in $3 \mathrm{rd}$ ed.

State Tax Reform for the Eighties, 16 Conn. L. Rev. 925 (1984) (festschrift issue); reprinted in Multistate Tax Commission Review (Oct. 1984); a revision of Improving a State's Tax System and its Administration Through a Major Tax Study, Revenue Administration--1983, p. 56 (1983).

Federal Tax Concepts as a Guide for State Apportionment of Dividends: Life After ASARCO, XVIII Tax Notes 411 (1982) (with R. Rudnick).

The Evolving Tax System of the People's Republic of China, 16 Tex. Int'l L.J. 11 (1981) (with S. Surrey and T. Gelatt); excerpted in LAW IN THE PEOPLE's REPUBLIC OF CHINA 495 (R. Folsom and J. Minan eds. 1986).

What is Happening to the Property Tax?, 7 J. Real Est. Tax'n 359 (1980); reprinted in 15 Assessors J. 107 (1980); and in Proceedings of the 72nd Annual Conference, National Tax Association--Tax Institute of America 10 (Bowers ed. 1980).

The Unitary Method: Thirteen Questions and Answers, X Tax Notes 891 (1980) (with Sen. F. Church); reprinted in Selected Reading on Tax Policy: 25 Years of Tax Notes.

The Tax Structure of the People's Republic of China, 20 Va. J. Int'l L. 1 (1979) (with S. Surrey), a substantial revision of Taxation in the People's Republic of China, in A New LoOK AT Legal AsPeCts OF DoING Business With ChinA 351 (H. Holtzmann and W. Surrey eds. 1979).

The Deduction of Property Taxes and Mortgage Interest: A Tax Expenditure Analysis, 1 Can. Tax'n 23 (1979).

Tax Measures in Response to the Brain Drain, 20 Harv. Int'l L.J. 1 (1979) (with O. Oldman).

Lifestyles and Land Use: Providing Financial Assistance Through the Tax System, in LAND USE AND LIFESTYLES 47 (1979).

Tax-Exempt Property and the Cities: Striking a Balance, 7 J. Real Est. Tax'n 50 (1979), a revision of Testimony Before the State Finance Committee's Subcommittee on Tax-Exempt Property, in ProPERTy TAX EXEMPTIONS FOR NON-PROFIT Institutions: PROBLEMS AND PROPOSALS 1 (1978), excerpted as Some Pay . . . 
Some Don't: Evaluating Property Tax Exemptions, 6 People and Taxes 4 (1978); reprinted in State AND LOCAL TAX REVOLT: NEW DiRECTIONS FOR THE 80'S at 178 (D. Tipps and L. Webb, eds. 1980).

The Brain Drain: A Tax Analysis of the Bhagwati Proposal, 3 World Dev. 751 (1975) (with O. Oldman), reprinted in TAXING THE BRAIN DRAIN: A PROPOSAL (J. Bhagwati and M. Partington eds. 1976).

\section{SUPREME COURT AMICUS BRIEFS}

Brief of Tax Law Professors as Amici Curiae in Support of Petitioner in Loudoun County, Virginia v. Dulles Duty Free, LLC (2018).

Brief of Amici Curiae Tax Law Professors and Economists in Support of Petitioner in South Dakota v. Wayfair, Inc. (2017).

Brief of Interested Law Professors as Amici Curiae Supporting Petitioner in Brohl v. Direct Marketing Association, 135 S. Ct. 1124 (2015).

Brief of Amici Curiae Fiscal Policy Institute, Connecticut Voices for Children and Good Jobs First in Support of Respondents in DaimlerChrysler Corp. v. Cuno, 547 U.S. 332 (2006).

Brief of Amicus Curiae Multistate Tax Commission in Support of Respondent in General Motors Corp. v. Tracy, 519 U.S. 278 (1997)

\section{MISCELLANEOUS}

Peter Faber, the Proverbial Lawyer's Intellectual and Intellectual Lawyer, 90 State Tax Notes 1051 (2019).

With Billions in 'Tax Expenditures,' Legislature Ignores Spending Cap, CT Mirror, December 22, 2011.

Malloy's Corporate Bets On ESPN And The 'First Five', Hartford Courant, August 1, 2011.

Huge Tax Grab Targeting Millstone Bad For Consumers, Business, Hartford Courant, April 24, 2011.

In Memoriam: Oliver Oldman, 122 Harv. Law. Rev. 1285 (2009).

Sales Taxes in the United States-Historical Development and Policy Analysis, 5 Warsaw University Law Review 86 (2006) (with M. Gradzki).

The Escheat of GifT CerTificAtes: Policy AND Legal Considerations 
(2005) (with R. Kay).

Revise the Property-Tax Exemption, The Chronicle of Philanthropy, May 2, 2002.

This Corporate Tax Break Will Cost Us Jobs, Hartford Courant, April 27, 2000 (with M. Mazerov).

Employee Visits and the Imposition of State Use Taxes on Out-of-State Sellers, in 1999 Institute on State and Local Tax (2000) (with Gall and Van Tifflin).

The Evolution of the Electric Utility Industry, 16 State Tax Notes 581 (1999).

Marvin Chirelstein: A Tribute, 29 Conn. L. Rev. 27 (1996).

The Disclosure of State Corporate Tax Data, NTA Forum (Summer, 1993).

Comment on Interstate Tax Competition After the Tax Reform Act of 1986, 12 Journal of Policy Analysis and Manag. 149 (1993).

Book Review, Li, Taxation in the People's Republic of China, 39 Can. Tax Rev. 1654 (1992).

Don't Count on Tax Cuts to Spur the Economy and Create Jobs, Hartford Courant, August 9, 1991.

Regionalization of Services and Taxes Needed for Central Cities, 19 Connecticut Town and Country 12 (1991).

The Like-Kind Exchange of Real Estate, in TAX PRACTICE SERIES (1989).

Book Review, McIntyre, The International Income Tax Rules of the United States, 43 Tax Notes 1543 (1989).

Connecticut's Faulty Tax Debate, Hartford Courant, September 17, 1989.

The Tax Treatment of Involuntary Conversions, in TAX PRACTICE SERIES (1989).

Foreword, Symposium Issue on State Tax Reform, 51 Alb. L. Rev. 369 (1987).

Night of the Murdered Poets, Hartford Courant, August 14, 1987 (with N. Lande).

The Call to "Give the Windfall Back"-To Which Taxpayers?, Hartford Courant, March 17, 1987; reprinted as Tax Reform: Is Connecticut Business Going to Pay More than its Fair Share?, New Haven Register, April 19, 1987; and as The 1986 Tax Reform Act: Windfall or Reparations to the State?, The Connecticut Law Tribune, April 20, 1987. 
China's New Foreign Tax Law: A Major Step, Asian Wall Street Journal, Dec. 22, 1981 (with T. Gelatt), reprinted as Foreign Enterprise Income Tax Law Adopted, 4 East Asian Executive Reports 3 (1982).

Do Chinese Income Taxes Qualify for the U.S. Foreign Tax Credit?, 3 East Asian Executive Reports 8 (1981) (with T. Gelatt).

The Victims of Property Tax Reform, N.Y. Times, June 15, 1980.

Can Tax Policy be Used to Stimulate Economic Development?, remarks prepared for the American University--Multistate Tax Commission's State and Local Business Tax Symposium, 29 Am. U.L. Rev. 207 (1980).

China's Taxes for Foreign Venturers, The Financial Times, June 11, 1980 (with O. Oldman).

Mortgage Plan Inefficient, Costly, Toronto Star, May 28, 1979; reprinted as Mortgage Deductibility Plan Has Pitfalls, Ottawa Journal, May 29, 1979.

Tax Exempt Property and Tax Capitalization in Central Cities: A Comment, Proceedings 6th Annual Conference, New England Business and Economic Association 53 (Koveos ed. 1979).

A Fairer Tax Share, N.Y. Times, April 9, 1978, reprinted in PROPERTY TAX EXEMPTIONS FOR NON-PROFIT INSTITUTIONS: PROBLEMS AND PROPOSALS 28 (1978).

Testimony Before the Finance Committee's Subcommittee on Tax Exempt Property, reprinted in PROPERTY TAX EXEMPTIONS FOR NON-PROFIT INSTITUTIONS: PROBLEMS AND PROPOSALS (1978).

Remarks Prepared for the Connecticut School Finance Seminar, in WHAT ARE CONNECTICUT'S CHOICES UNDER HORTON V. MESKILl 19 (1978).

Discussion Draft Prepared for the Greater Hartford Chamber of Commerce's Task Force on Tax Exempt Property, in PROPERTY TAX EXEMPTIONS FOR NON-PROFIT InSTITUTIONS: PROBLEMS AND PROPOSALS 10 (1978).

The United States Interest Equalization Tax, 28 Bull. for Int'l Fiscal Doc. 3 (1974).

Comparative Analysis of Depreciation in the Common Market: United Kingdom, 12 Eur. Tax 190 (1972). 


\section{MINOR REVIEWS}

Book Review, 38 State Tax Notes 555 (2005) (reviewing Arthur Rosen and Susan Hattfield, Sales and Use Taxes: Streamlined Sales Tax System).

Book Review, 31 State Tax Notes 67 (2004) (reviewing David Brunori, Local Tax Policy, A Federalist Perspective).

Book Review, 21 State Tax Notes 771 (2001) (reviewing David Brunori, State Tax Policy: A Political Perspective).

Book Review, 13 Tax Notes International 1229 (1996) (reviewing McIntyre \& Arnold, International Tax Primer).

Book Review, 5 State Tax Notes 261 (1993) (reviewing U.S. General Accounting Office, Balanced Budget Requirements: State Experiences and Implications for the Federal Government (1993)).

Book Review, 5 State Tax Notes 262 (1993) (reviewing F. Stocker ed., A Look at State and Local Tax Policies: Past Trends and Future Prospects (1991)).

Book Review, 5 State Tax Notes 263 (1993) (reviewing R. Broadway \& A. Hobson, Intergovernmental Fiscal Relations in Canada (1993)).

Book Review, 5 State Tax Notes 264 (1993) (reviewing W. Duncombe, Economic Change and the Evolving State Tax Structure: The Case of the Sales Tax (1992)).

Book Review, 5 State Tax Notes 264 (1993) (reviewing W. Fox, Sales Taxation: Critical Issues in Policy and Administration (1992)).

Book Review, 5 State Tax Notes 264 (1993) (reviewing J. \& W. Hellerstein, State Taxation, Vol. 1: Corporate Income and Franchise Taxes (1993)).

Book Review, 5 State Tax Notes 265 (1993) (reviewing City of New York, New York City Annual Report on Tax Expenditures (1992)).

Book Review, 5 State Tax Notes 265 (1993) (reviewing T. Pogue, State Taxation of Business: Issues and Policy Options (1992)).

Book Review, 4 State Tax Notes 347 (1993) (reviewing Proposition 13: A Ten- Year Retrospective (R. Stocker ed., 1991)).

Book Review, 4 State Tax Notes 347 (1993) (reviewing W. Oates, Studies in Fiscal Federalism (1991)). 
Book Review, 4 State Tax Notes 348 (1993) (reviewing B. Roberts, Competition Across the Atlantic: The States Face Europe '92 (1991)).

Book Review, 4 State Tax Notes 349 (1993) (reviewing Canadian Tax Foundation, Provincial and Municipal Finances 1991 (1992)).

Book Review, 5 Tax Notes International 894 (1992) (reviewing B. Terra, Introduction to Value Added Tax in the E.C. After 1992 (1992)).

Book Review, 5 Tax Notes International 1043 (1992) (reviewing M. McIntyre, The International Income Tax Rules of the United States (2d ed. 1992)).

Book Review, 5 Tax Notes International 1043 (1992) (reviewing M. McIntyre, International Tax Workbook: 1992 (1992)).

Book Review, 5 Tax Notes International 893 (1992) (reviewing World Bank, Lessons of Tax Reform (1991)).

Book Review, 5 Tax Notes International 892 (1992) (reviewing A. Skaar, Permanent Establishment: Erosion of a Tax Treaty Principle (1991)).

Book Review, 5 Tax Notes International 892 (1992) (reviewing V. Tanzi, Public Finance in Developing Countries (1992)).

Book Review, 5 Tax Notes International 893 (1992) (reviewing R. Bramwell, Taxation of Companies and Company Reconstructions (1991)).

Book Review, 4 Tax Notes International 488 (1992) (reviewing A. Daniels, Issues in International Partnership Taxation (1992)).

Book Review, 4 Tax Notes International 1158 (1992) (reviewing R. Sunders, Structuring International Real Estate Transactions (1992)).

Book Review, 4 Tax Notes International 488 (1992) (reviewing A. Razin \& J. Slemrod, Taxation in the Global Economy (1990)).

Book Review, Tax Notes International 487 (1992) (reviewing J. Li, Taxation in the People's Republic of China (1991)).

Book Review, 39 Canadian Tax Journal 1654 (1991) (reviewing J. Li, Taxation in the People's Republic of China (1991)).

Book Review, 3 Tax Notes International 339 (1991) (reviewing C. Brown, Tax Aspects of the Transfer Technology: The Asia-Pacific Rim (1991)). 
Book Review, 3 Tax Notes International 340 (1991) (reviewing J. Whalley \& D. Fretz, The Economics of the Good and Services Tax (1991)).

Book Review, 3 Tax Notes International 1029 (1991) (reviewing J. Tirard, Corporate Taxation in E.C. Countries: 1990-91 (1991)).

Book Review, 3 Tax Notes International 1030 (1991) (reviewing B. Bittker \& L. Lokken, Fundamentals of International Taxation: U.S. Taxation of Foreign Income and Foreign Taxpayers (1991)).

Book Review, 3 Tax Notes International 1030 (1991) (reviewing B. Arnold, Tax Discrimination Against Aliens, Nonresidents, and Foreign Activities: Canada, Australia, New Zealand, the United Kingdom, and the United States (1991)).

Book Review, 3 Tax Notes International 1361 (1991) (reviewing A. Razin \& J. Slemrod, Taxation in the Global Economy (1991)).

Book Review, 3 Tax Notes International 339 (1991) (reviewing A. Easson \& J. Li, Taxation of Foreign Investment in the People's Republic of China (1991)).

Book Review, 3 Tax Notes International 1031 (1991) (reviewing U.S. Tax Treatment of Financial Transactions Involving Foreign Currency (1991)).

Book Review, 3 Tax Notes International 1031 (1991) (reviewing M. Boskin \& C. McLure, Jr., World Tax Reform: Case Studies of Developed and Developing Countries (1991)).

Book Review, 3 Tax Notes International 340 (1991) (reviewing J. Whaller, The Economics of the Goods and Services Tax (1990)).

Book Review, 2 Tax Notes International 418 (1990) (reviewing R. Doernberg, International Taxation (1990)).

Book Review, 43 Tax Notes 1543 (1989) (reviewing M. McIntyre, The International Income Tax Rules of the United States (1989)). 